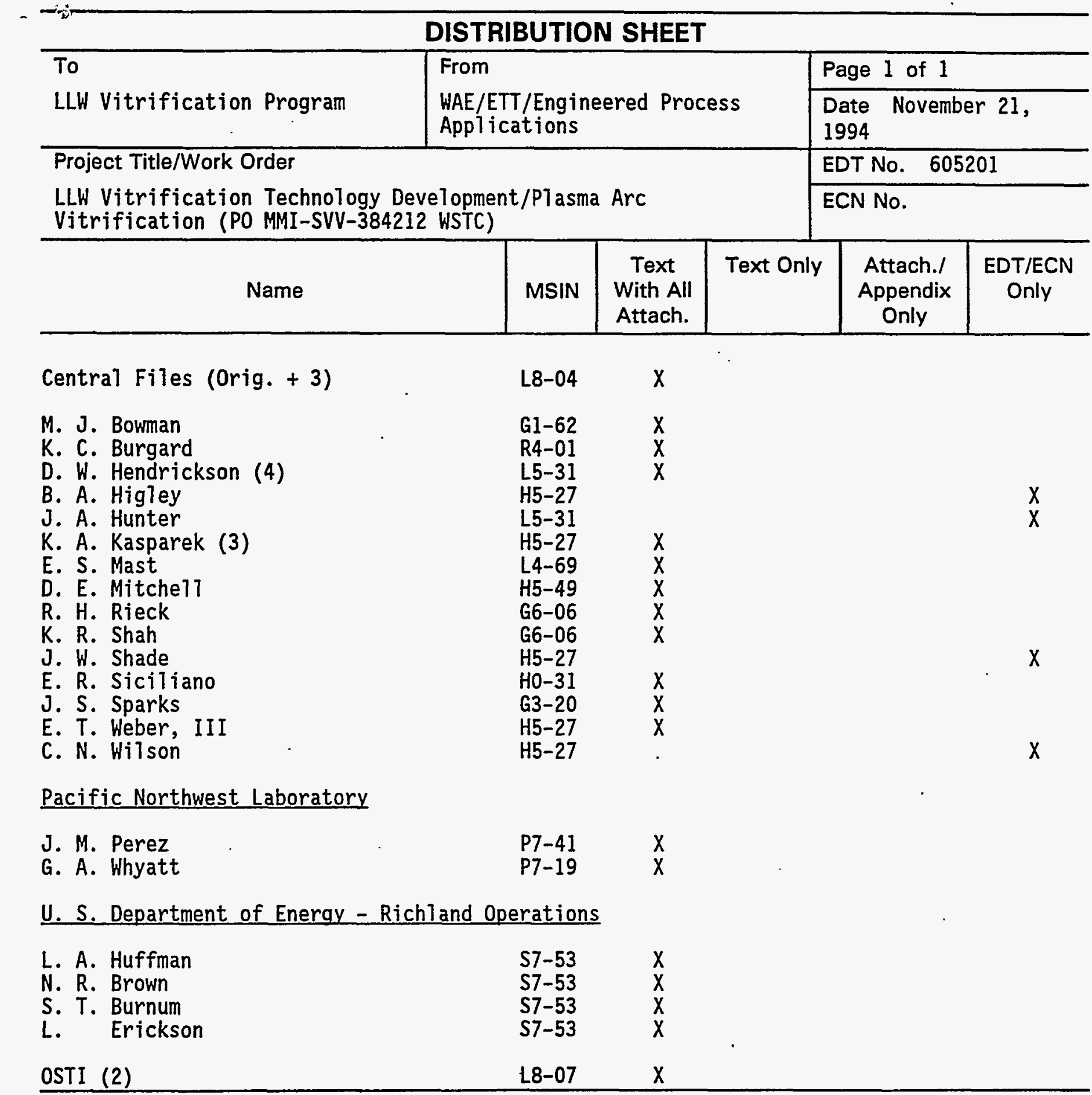




\section{DISCLAIMER}

Portions of this document may be illegible in electronic image products. Images are produced from the best available original document. 
$\ell$

DEC 2199421 tNGINEERING Data transmittal

+ 2

2. To: (Receiving Organization)

TWRS Vitrification

Development

5. Proj./Prog./Dept./Div.:

TWRS LLW Program

8. Originator Remarks:

Westinghouse Science and Technology Center (WSTC) Plasma Arc Vitrification, Phase I, melter test plan for approval and issuance.

11. 'Receiver Remarks:
3. From: (Originating Organization) WAE/ETT/Engineered Process Applications

6. Cog. Engr.:

D. W. Hendrickson

4. Related EDT No.:

156363

7. Purchase Order No.: MMI-SVV-384212 WSTC

9. Equip./Component No.: $N / A$

10. System/Bidg./Facility: $N / A$

12. Major Assm. Dwg. Mo.: $N / A$

13. Permit/Permit Application Ho.: $N / A$

14. Required Response Date: November 23, 1994

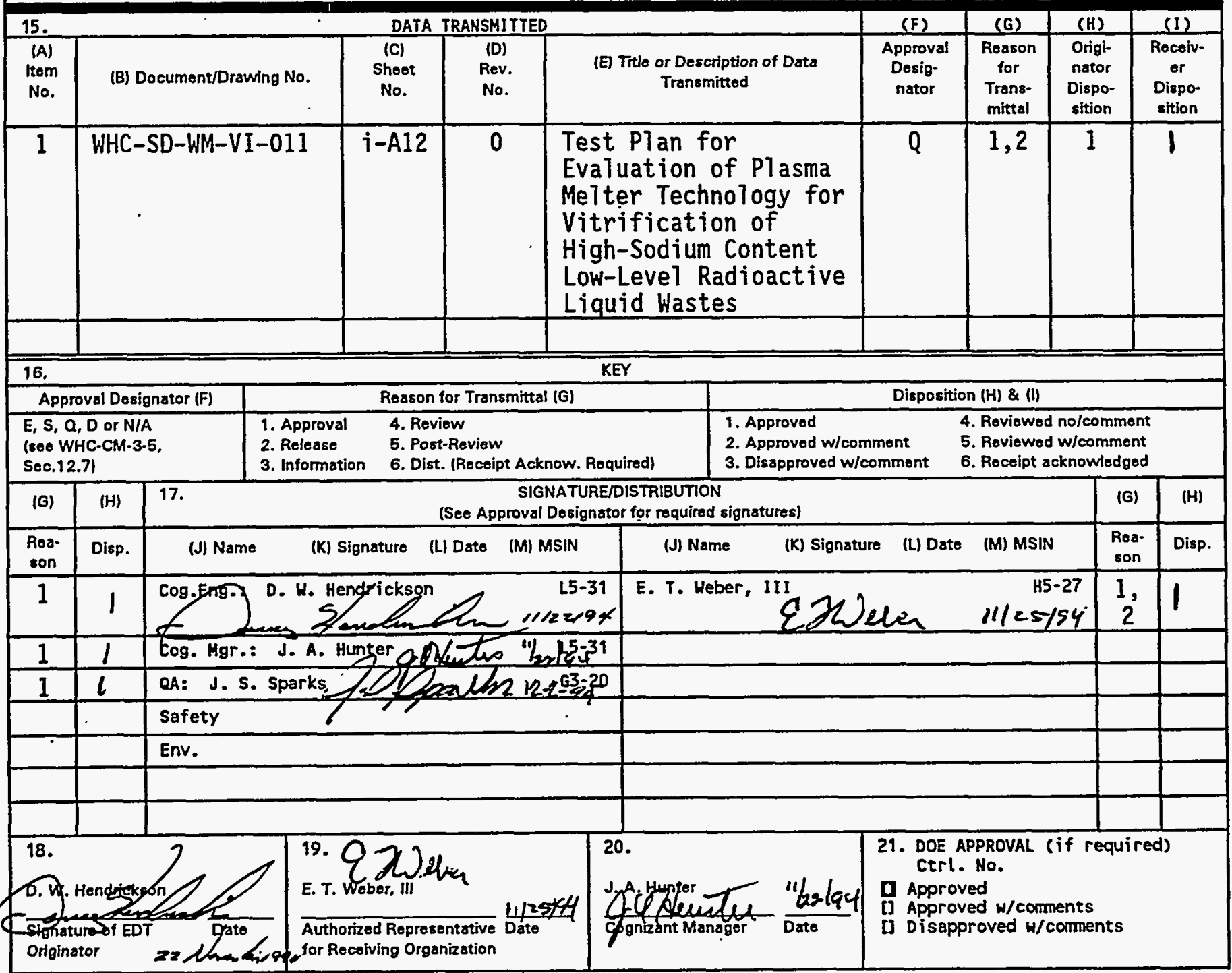

BD-7400-172-2 (04/94) GEF097 
RELEASE AUTHORIZATION

\begin{tabular}{|ll}
\hline Document Number: & WHC-SD-WM-VI-011, REV. 0 \\
\hline Document Title: & $\begin{array}{l}\text { Test Plan for Evaluation of Plasma Melter Technology } \\
\text { for Vitrification of High-Sodium Content Low-Level } \\
\text { Radioactive Liquid Wastes }\end{array}$ \\
\hline
\end{tabular}

Release Date:

$12 / 02 / 94$

This document was reviewed following the
procedures described in WHC-CM-3-4 and is:

APPROVED FOR PUBLIC RELEASE

WHC Information Release Administration Specialist:

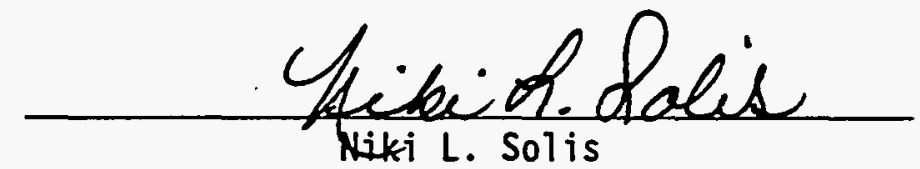

TRADEMARK DISCLAIKER. Reference herein to any specific commercial product, process, or service by trade name, trademark, manufacturer, or otherwise, does not necessarily constitute or imply its endorsement, recormendation, or favoring by the United States Government or any agency thereof or its contractors or subcontractors.

This report has been reproduced from the best available copy. Available in paper copy and microfiche. Printed in the United States of America. Available to the U.S. Department of Energy and its contractors from:

U.S. Department of Energy

Office of Scientific and Technical Information (OSTI)

P.0. Box 62

Dak Ridge, IN 37839

Telephone: (615) 576-8401

Available to the public from:

U.S. Department of Commerce

National Technical Information Service (NTIS)

5285 Port Royal Road

Springfield, VA 22161.

Telephone: (703) $487-4650$

\section{DISCLAIMER}

This report was prepared as an account of work sponsored by an agency of the United States Government. Neither the United States Government nor any agency thereof, nor any of their employees, makes any warranty, express or implied, or assumes any legal liability or responsibility for the accuracy, completeness, or usefulness of any information, apparatus, product, or process disclosed, or represents that its use would not infringe privately owned rights. Reference herein to any specific commercial product, process, or service by trade name, trademark, manufacturer, or otherwise does not necessarily constitute or imply its endorsement, recommendation, or favoring by the United States Government or any agency thereof. The views and opinions of authors expressed herein do not necessarily state or reflect those of the United States Government or any agency thereof.

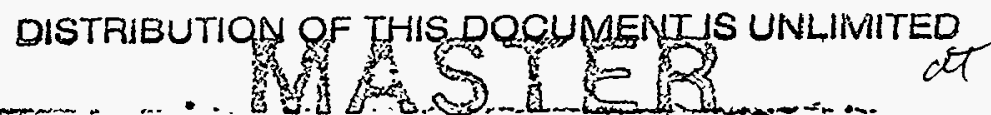




\section{Title}

Test Plan for Evaluation of Plasma Melter Technology for Vitrification of High-Sodium Content LoH-Leve1 Radioactive Liquid Wastes

5. Key Hords

Nuclear. Radioactive. LLH. Waste. Vitrification. Glass. Plasma. Disposal. Melting. Testing. Hanford. Sodium.

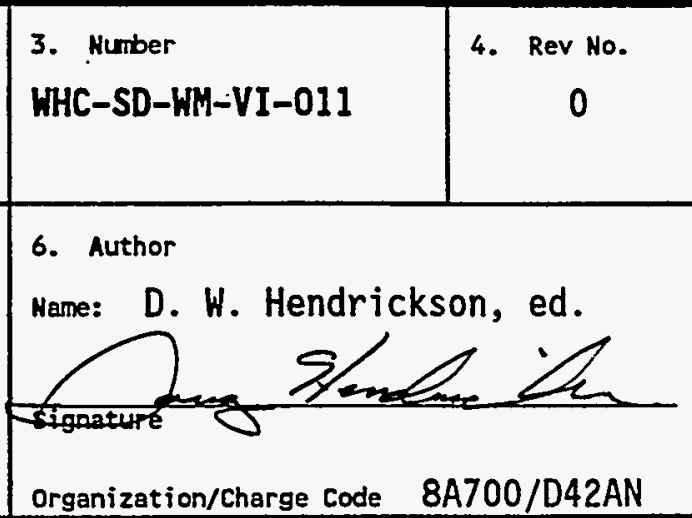

\section{Abstract}

This document provides a test plan for the conduct of plasma arc vitrification testing by a vendor in support of the Hanford Tank Waste Remediation System (TWRS) Low-Level Waste (LLW) Vitrification Program. The vendor providing this test plan and conducting the work detailed within it [one of seven selected for glass melter testing under Purchase Order MMI-SVV-384212] is the Westinghouse Science and Technology Center (WSTC) in Pittsburgh, PA.

WSTC authors of the test plan are D. F. McLaughlin, E. J. Lahoda, W. R. Gass, and N. D'Amico. The WSTC Program Manager for this test is D. F. McLaughlin.

This test plan is for Phase I activities described in the above Purchase Order. Test conduct includes melting of glass frit with Hanford LLW Double-Shell Slurry Feed waste simulant in a plasma arc fired furnace. 


\title{
Test Plan for Evaluation of Plasma Melter Technology for Vitrification of High-Sodium Content Low-Level Radioactive Liquid Wastes
}

\author{
D. F. McLaughlin , E. J. Lahoda, W. R. Gass, and N. D'Amico \\ Environmental Technologies
}

October 20, 1994

Contract No. DE-AC06-87RL10930

Westinghouse Hanford Company

P.O. Box 1970

Richland, WA 99532

M. Bowman, WHC Contracting Officer

STC General Order Reference: MMI-SVV-384212

APPROVED:

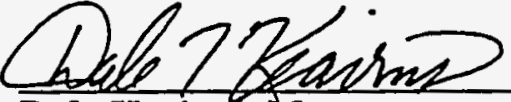

Dale Keairns, Manager

Environmental Technologies

\section{Westinghouse STC}


Document Title: Test Plan for Evaluation of Plasma Melter Technology for Vitrification of High-Sodium Content Low-Level Radioactive Liquid Waste

Prepared by:
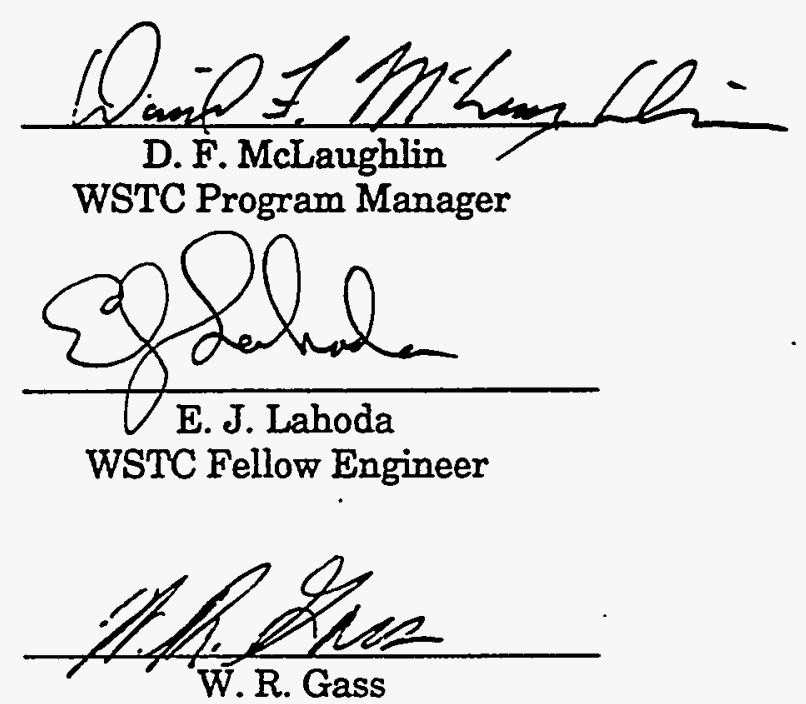

WSTC Project Engineer

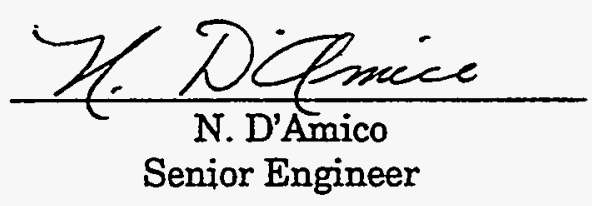

Approved by:

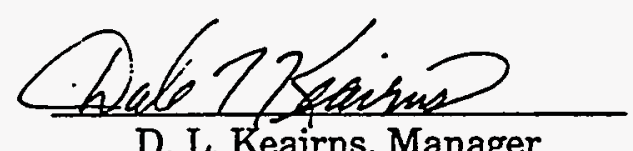

WSTC Environmental Technologies Manager

Approved by:

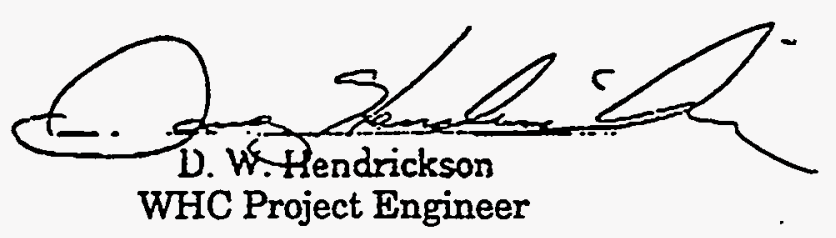




\section{CONTENTS}

CONTENTS iii

LIST OF TABLES. vi

LIST OF ABBREVIATIONS. vii

ABSTRACT viii

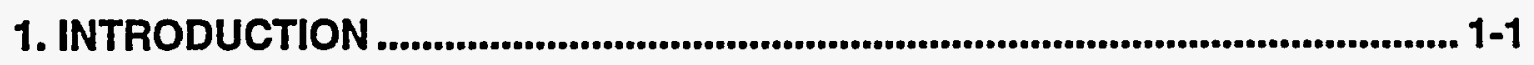

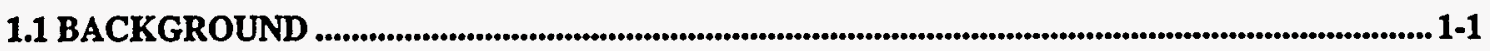

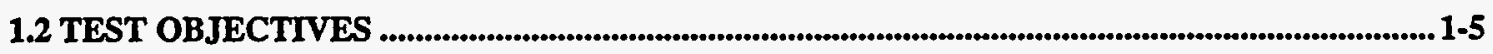



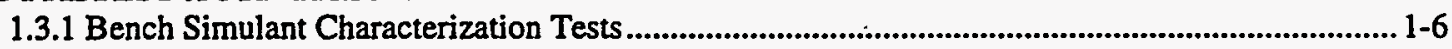

1.3.2 Glass Composition Definition ........................................................................................................... 1-7

1.3.3 Plasma Melter Facility Modifications and Upgrades .................................................................... 1-8

1.3.4 Pre-Demonstration Trial Heats................................................................................................... 1-10

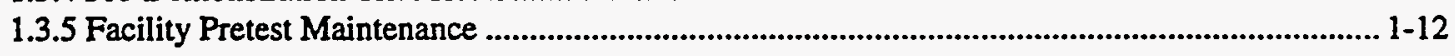

2. MELTER SYSTEM DESCRIPTION ....................................................................... 2-1

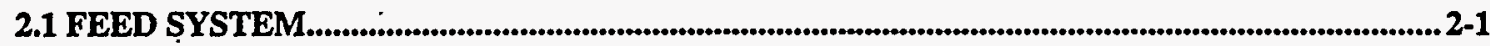

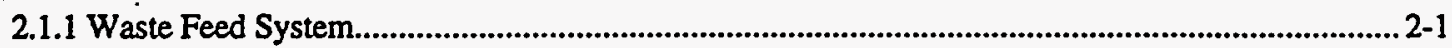

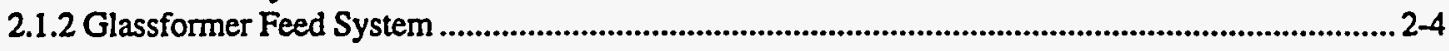

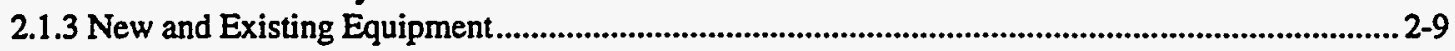

2.2 PILOT SCALE MELTER SYSTEM.................................................................................................. 2-11

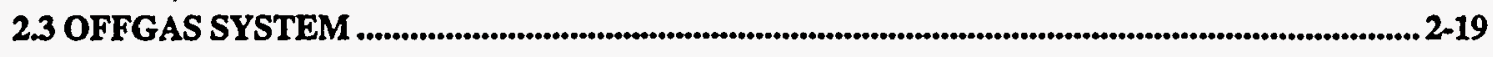

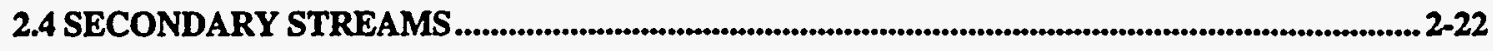

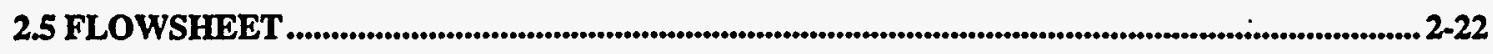

3. TEST MONITORING AND SAMPLING ............................................................... 3-1

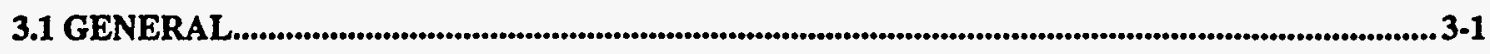


3.3 SAMPLING 3-6

3.3.1 Sample Numbering System .

3.3.2 Sample Labeling .

3.3.3 Chain of Custody

3.3.4 Sample and Shipping Log

3.4 DETERMINING LIMITS ON SO $4, \mathrm{Cl}_{4} \mathrm{PO}_{4}, \mathrm{~F}$ AND CrO

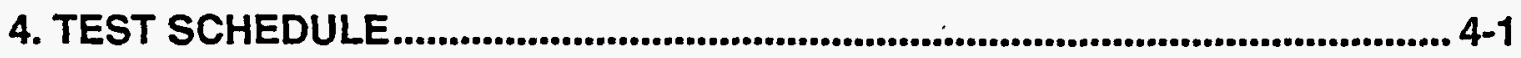

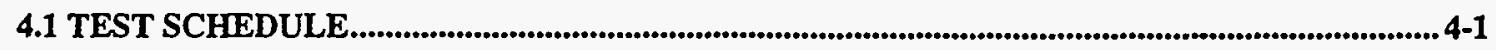

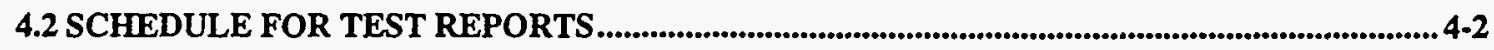

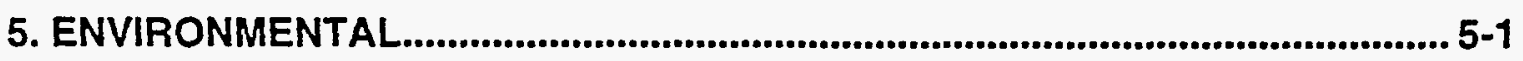

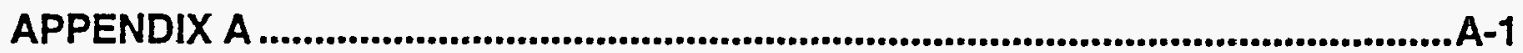


WHC-SD-WM-VI-011

Revision 0

\section{LIST OF FIGURES}

Figure 1.1 - Schematic of Plasma Melter Pilot Plant Facility 1-2

Figure 2.1 - Westinghouse Plasma Melter for the Vitrification of Simulated Low-Level

Waste 2-2

Figure 2.2 - Liquid/Slurry Feed System for Feeding Simulated Low-Level Waste..... 2-3

- Figure 2.3 - Diagram of the Crucible Portion of the 14 ton per day Plasma Melter.. 2-14

Figure 2.4 - Schematic of Plasma Melter System Instrumentation........................... 2-15

Figure 2.5 - Cross-section of the Westinghouse Marc 11 Plasma Torch. ................... 2-16

Figure 2.6 - Plasma Torch Systems Instrumentation Diagram ................................ 2-17

Figure 2.7 - Sampling and Process Measurement Locations in Offgas System......... 2-20

Figure 2.8 - Durability of SRTC Glass Formulations Compared to EA Glass ........... 2-25

Figure 3.1 - Melter Project: Sample Numbering Scheme - WSTC............................. 3-8

Figure 3.2 - Sample and Shipping Log - WSTC ....................................................... 3-12 
WHC-SD-WM-VI-011

Revision 0

\section{LIST OF TABLES}

Table 1.1 - Waste Composition $1-9$

Table 2.1 - Comparative Offgas Generation from Various Vitrification Configurations2-8

Table 2.2 - Table of Existing and New Feed System Equipment. 2-10

Table 2.3 - Offgas Generation from Plasma Vitrification........................................... 2-18

Table 2.4 - Predicted Final Glass Composition $2-24$

Table 3.1 - Sample and Data Collection Schedule $3-3$

Table 3.2 - Pre and Post Demonstration Test Inspections . $3-5$

Table 3.3 - Expected Concentration of Low-Solubility Salts in Glass. 3-14

Table 4.1 - Demonstration Test Chronology 4-2

Table 4.2 - Technical Documentation Delivery Schedule 4-3 
WHC-SD-WM-VI-011

Revision 0

\section{LIST OF ABBREVIATIONS}

ALARA

DOE

DWPF

EA

EPA

HEME

HIW

HX

LLRW

ILW

NASA

PADER

PC

PCT

PLC

PVC

QA

RCRA

RTD

SOW

SPTD

SRTC

WDS

WHC

WSTC
As low as reasonably achievable

Department of Energy

Defense Waste Processing Facility

Reference to PCT Baseline Savannah River

Environmental Assessment Glass Composition

United States Environmental Protection Agency

High Efficiency Mist Eliminator

High-level Waste

Heat Exchanger

Low-level Radioactive Waste

Low-level Waste

National Aeronautics and Space Administration

Pennsylvania Department of Environmental Resources

Personal Computer

Product Control Test

Process Logic Controller

Polyvinyl Chloride

Quality Assurance

Resource Conservation and Recovery Act

Resistance Temperature Device

Statement of Work

Systems, Processes and Technologies Division

Savannah River Technology Center

Wavelength Dispersive X-ray Fluorescence Spectroscopy

Westinghouse Hanford Company

Westinghouse Science \& Technology Center 
WHC-SD-WM-VI-011

Revision 0

\section{ABSTRACT}

A test plan is presented for demonstration of vitrification of simulated highsodium content low-level nuclear waste, using the Westinghouse Plasma Melter Technology. The test plan includes description of the Plasma Center pilot melter facility, plans for facility upgrade and modifications, three pre-test trial heats for equipment shakedown and feed system optimization, schedule and procedure for data collection and sample acquisition, and a proposed schedule for testing. 


\section{INTRODUCTION}

Three preliminary tests and one long term test on the vitrification of high sodium low level nuclear waste simulant will be carried out by the Westinghouse Science and Technology Center (WSTC) at the Westinghouse Plasma Center at the Waltz Mill site at Madison, $\mathrm{Pa}$ using plasma melter technology. These tests make up the Phase 1 tests required for this contract. This document provides a detailed description of what will be accomplished by these tests, what equipment will be used, how this equipment will be operated, what data will be acquired, and how the data will be analyzed.

\subsection{BACKGROUND}

The Westinghouse Plasma Melter is the basis for the vitrification process proposed by Westinghouse STC for Hanford's low-level waste. The Plasma Melter, although non-conventional for low-level radioactive waste vitrification, has been tested successfully on two occasions by Westinghouse for calcination of simulated high-level waste containing in excess of $15 \mathrm{M}$ sodium salts. In the 1993 test, 3.5 tonnes of Hanford simulated high level waste slurry were fed to the Plasma Melter, producing $1300 \mathrm{~kg}$ of molten calcine at temperatures of 650 to $1000^{\circ} \mathrm{C}$. These results are the basis for the test program proposed here.

The heart of the vitrification process is the plasma fired vitrification reactor, shown in Figure 1.1. The configuration shown is that of the existing pilot-scale 2.3 tonne/day plasma melting facility at the WSTC Waltz Mill Plasma Center. This reactor consists of a 6-meter vertical shaft, having a $0.76 \mathrm{~m}$ inside diameter. The shaft is 


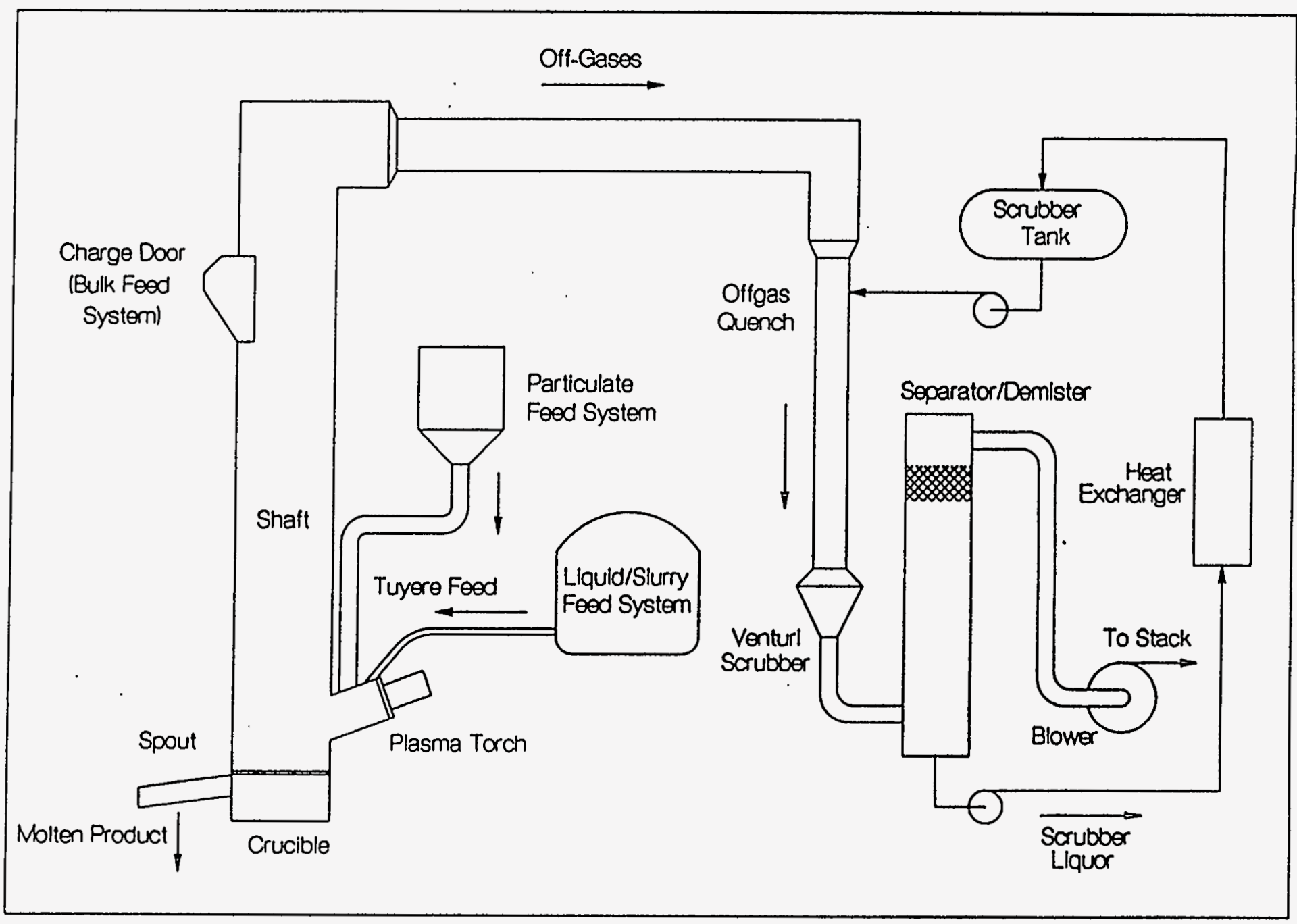

PLASMAVLOTIPCO

Figure 1.1 - Schematic of Plasma Melter Pilot Plant Facility 
refractory lined, as is the melt zone (known as the crucible). Process heat is supplied by a Westinghouse non-transferred arc plasma torch, mounted to one side of the crucible zone in an entry duct known as the tuyere.

The waste solution or slurry is injected directly into this tuyere through a simple straight-pipe injection nozzle, at sufficient velocity to cause rapid mixing of the waste with the extremely hot $\left(5000^{\circ} \mathrm{C}\right)$ plume generated by the plasma torch. The water content of the waste is flashed to steam, with a mixing temperature well in excess of $2000^{\circ} \mathrm{C}$. Decomposition of the nitrates and nitrites in the waste mixture occurs, as was demonstrated in the 1993 Plasma Melter tests on Hanford HLW simulant.

Several benefits derive from this in-situ calcination process, including low $\mathrm{NO}_{x}$ generation. Detailed modeling of this process has been carried out by WSTC, using the CET89 Chemical Equilibrium Thermodynamics computer based simulator (developed by NASA Lewis Research Center) $)^{1}$ coupled with the Westinghouse proprietary CHEMEQ thermochemical database. At the very high heating rates experienced by nitrates and nitrites in the tuyere, decomposition is predicted to occur completely, with nearly quantitative conversion to the reaction products favored by chemical equilibrium, namely innocuous $\mathrm{N}_{2}$ and $\mathrm{O}_{2}$ gases. When the resulting decomposition gases are cooled to the melter operating temperature of $1150^{\circ} \mathrm{C}$, an equilibrium $\mathrm{NO}_{z}$ concentration of less than $700 \mathrm{ppm}$ is predicted, representing less than $0.7 \%$ of nitrate/nitrite nitrogen provided as feed.

The Westinghouse non-transferred arc plasma torch is a rugged and commercially available technology. The working gas (air, nitrogen, or any of a variety of other gases) is injected into the gap between the electrodes, and an arc discharge struck between them. The high velocity of the gas carries the arc into the throat of the torch, and heats the working gas to extremely high temperatures. Field coils rotate the electrically conductive plasma at high rotational velocities, such that the point of contact of the arc with the downstream electrode is constantly moving. This feature prevents ablation of the electrode, and leads to electrode lifetimes in excess of 1,000 hours before replacement. The superheated gases, now electrically recombined to

\footnotetext{
'R. A. Svehla and B. J. McBride, NASA Technical Note TN-D-7056, National Aeronautics and Space Administration, Lewis Research Center, Cleveland OH, January, 1973.
} 
neutral atoms and molecules, exit the torch into the tuyere at high velocity. Additional gas is injected at this point (the shroud gas), maintaining a cooler gas blanket between the torch plume and the refractory lining, protecting the refractory.

A unique attribute of the non-transferred arc torch is its ability to decouple and independently control the gas temperature and chemistry. The torch is capable of operating on air (the most common choice due to economic consideration), nitrogen (if oxidizing conditions are to be avoided), hydrogen (providing a reducing chemistry), or inert gases such as helium or argon (suppressing all arc chemistry). Chemically active gases such as oxygen or even chlorine may also be used. Minimization of the quantity of non-condensible offgas generated by the plasma vitrification system might be accomplished by the use of steam as the shroud gas.

Because of the simplicity of its construction, maintenance on the Westinghouse plasma torch is simple and requires little time. In typical industrial operations, the plasma torch is connected to the melter by simple flange connections. Disconnection of four bolts, two electrical connectors, and two cooling water quick-connect fittings allows the torch to be changed out in less than fifteen minutes. Replacement of the electrodes is also a quick operation, requiring less than an hour total labor time.

The feed system for Phase 1 testing is based on the successful configuration developed during the 1993 calcination tests. A large tank is provided with both mechanical agitation and a recirculation system consisting of several parallel loops of varying diameter and flow velocity. Sufficiently high recirculation flowrates are provided to keep slurry particles in suspension. In the 1993 tests a slurry/solution mixture containing in excess of 15 molar sodium salts was fed to the plasma melter; chemical and percent suspended solids analysis of the resulting feed material showed variability over nearly 8 hours of operation of less than a few percent. Injection of the waste slurry occurs directly above the plasma plume in the tuyere, resulting in rapid mixing of the waste and the superheated gases, evaporation of the water fraction, and calcination of the nitrates and nitrites.

Glassformers will be added in the form of premelted frit through a metered solids feed auger. This material is either preblended with waste simulant and injected by a progressing cavity pump into the tuyere, or added at the top of melter shaft along with metallurgical grade coke (see detailed discussion in Section 2.1). 
WHC-SD-WM-VI-011

Revision 0

The off-gas treatment system provides for quenching, scrubbing, and filtration before atmospheric discharge. Hot shaft offgases are quenched in the lower section of the quench tower and then scrubbed in a high-efficiency venturi scrubber. The expected removal efficiency of these two operations has been demonstrated to be greater than 99\%. The cooled gas enters a High Efficiency Mist Eliminator (HEME, also having a removal efficiency greater than 99\%), where water droplets are removed. A regenerative blower provides the draft for the air handling system, ensures that the entire offgas system operates at negative pressure relative the surroundings, and discharges the gas to the process vent system.

\subsection{TEST OBJECTIVES}

The objectives of the testing are as follows:

1. Demonstrate feasibility of using the plasma melter for vitrifying high-sodium liquid waste at high throughput ( 0.4 to 0.6 tonne/hr of glass) with effective process and product control.

2. Demonstrate a practical and reliable feed system capable of supplying a consistent feed of LLW simulant and glass formers to the plasma melter to provide a consistent glass product at the target composition.

3. Acquire process data necessary to demonstrate scaling potential of the plasma melter to 4 to 8 tonnes/hr throughput of glass product.

4. Perform a material balance around potentially volatile components ( $\mathrm{Cs}, \mathrm{Na}$, $\mathrm{K}, \mathrm{B}, \mathrm{Mo}$ (a Tc simulant), $\mathrm{SO}_{2}, \mathrm{~F}, \mathrm{I}$, and $\mathrm{Cl}$ ) to determine their partitioning between the off-gas and the glass product.

5. Characterize the offgas as to flowrate, composition (CO, $\mathrm{CO}_{2}, \mathrm{H}_{2}, \mathrm{NO}_{2}$ and $\mathrm{SO}_{2}$ ), and aerosol entrainment.

6. Identify formation of separated phases and develop information to assess limits of $\mathrm{PO}_{\star}, \mathrm{SO}_{\iota}, \mathrm{F}$, and $\mathrm{Cl}$ in the $\mathrm{LLW}$ feed which can be successfully processed.

7. Establish requirements for feed processing, offgas treatment, and secondary waste disposal. 
8. Obtain the data required to support WHC engineering studies on life cycle costs, system reliability, overall system design, and maintenance requirements.

\subsection{PRETEST ACTIVITIES}

Pretest activities and the sections describing these activities are:

1. Bench simulant characterization tests by Westinghouse STC (Section 1.3.1).

2. Integration of the glass composition definition developed by the Savannah River Technology Center (SRTC) for WSTC into the Phase 1 test program (Section 1.3.2).

3. Modification and upgrading of the plasma facility to perform the required testing (Section 1.3.3).

4. Completion of three pre-demonstration trial heats (Section 1.3.4).

5. Facility pretest maintenance and baselining (Section 1.3.5).

\subsubsection{Bench Simulant Characterization Tests}

Upon receipt of samples of simulated Hanford LLW and glass frit, bench scale testing will be carried out to determine characteristics which will be pertinent to the demonstration tests. Properties will be measured as appropriate for the raw waste alone, the glass frit alone, and the combined waste plus glass frit. These tests will include:

1. $\mathrm{pH}$

2. percent total solids after drying at $110^{\circ} \mathrm{C}$;

3. suspended solids (raw waste only);

4. settling time of suspended solids;

5. specific gravity; and

6. viscosity.

In addition, SRTC will supply the following:

7. glass density as a function of temperature;

8. glass viscosity as a function of temperature; and

9. glass leaching behavior. 
These characteristics will be used to verify the sizing of the process feed system and identify any changes which will be required. In addition, these characteristics will also be used to identify potential operational, control, and safety problems over and above those already anticipated based on WSTC's previous experience.

\subsubsection{Glass Composition Definition}

This task has been performed by the Savannah River Technology Center for WSTC, each under contract to Westinghouse Hanford Company (WHC). Results were transmitted to WSTC as required to maintain the proposed test schedule. The specifications (weight percent) for the glass frit and final glass which have been developed are as follows (SRTC Composition \#4 with $0.66 \% \mathrm{Al}_{2} \mathrm{O}_{3}$ replaced by $\mathrm{Fe}_{2} \mathrm{O}_{3}$ as an oxidation- reduction tracer):

1. Glassformer Composition: Glass Composition:

$\begin{array}{lrr}\mathrm{SiO}_{2} & 57.20 \% & 42.90 \% \\ \mathrm{Al}_{2} \mathrm{O}_{3} & 19.44 \% & 17.77 \% \\ \mathrm{~B}_{2} \mathrm{O}_{3} & 12.60 \% & 9.45 \% \\ \mathrm{CaO} & 6.20 \% & 4.65 \% \\ \mathrm{ZrO}_{2} & 2.80 \% & 2.10 \% \\ \mathrm{Li}_{2} \mathrm{O} & 1.10 \% & 0.83 \% \\ \mathrm{Fe}_{2} \mathrm{O}_{3} & 0.66 \% & 0.50 \% \\ \mathrm{Na}_{2} \mathrm{O} & 0.00 \% & 18.12 \% \\ \text { Other } & 0.00 \% & 3.68 \%\end{array}$

2. Melting point of final glass: $1150^{\circ} \mathrm{C}(\leq 100$ poise viscosity)

3. Evaluated durability (leaching) to exceed performance of the Environmental Assessment (EA) glass formulation ${ }^{2}$ used for baseline development of the Savannah River Product Consistency Test (PCT) for glass durability with respect to leaching. ${ }^{3}$

4. No second phase formation.

\footnotetext{
${ }^{2}$ C. M. Jantzen, et al., "Characterization of the Defense Waste Processing Facility (DWPF) Environmental Assessment (EA) Glass Standard Reference Material," Westinghouse Savannah River Company, WSRC-TR-92-346, Rev. 1, June 1, 1993.

"C. M. Jantzen, et al., "Test Method Relative to Durability of Nuclear Waste Glasses," ASTM Standard Procedure C1285-94, 1994.
} 
These specifications are achieved using a $25 \%$ waste loading with the composition specified in Table 1.1, with the complete glass composition detailed in Table 2.2, Section 2.5 below. Verification tests have been conducted by SRTC to ensure that the glass composition will meet the above specifications. These tests have included small crucible coupons of glass fabricated from virgin chemical glassformers and waste simulant, subjected to a modified 3-day Product Consistency Test leaching. Larger scale (40 kg) melts of the proposed glass composition have also been carried out to ensure processability and characterize volatile losses and second phase formation. Results of the coupon tests are presented in Section 2.5 below; results of the larger scale melts will be reported later.

No particle size specification exists for supply of this material as frit. The particle size range for Savannah River DWPF frit is $-80 /+200$ mesh ( 88 to $177 \mu \mathrm{m}$ ), but this reflects the dual usage of the frit for both glass forming and grit blasting of finished high-level waste canisters which mandates the $>88 \mu \mathrm{m}$ specification; elimination of fines greatly increases the cost of glassformer frit. Bench testing of waste-frit slurry viscosity and settling properties will determine whether the fines can be accepted in the current test program. Finer glassformers will be required for tuyere injection, while a coarse material is desirable for top loading with coke.

\subsubsection{Plasma Melter Facility Modifications and Upgrades}

Some modifications to the plasma melter, located at the Westinghouse Plasma Center, are required before testing is initiated. The facility is described in detail in Sections 2.1, 2.2 and 2.3. The modifications are being made to provide the optimum operating conditions for processing the Hanford waste. These modifications include:

1. Sealing of charge door to prevent air infiltration (lowering the amount of gas/volume of waste treated and allowing more accurate material balance calculations).

2. Installation of larger feed tank capable of providing simulant feed at 25 to $90^{\circ} \mathrm{C}$ for the entire test run. 
Table 1.1 - Waste Composition

\begin{tabular}{|c|c|c|c|c|c|c|c|c|c|}
\hline \multirow[b]{2}{*}{ Component } & \multirow[b]{2}{*}{ Compound } & \multirow[b]{2}{*}{$\begin{array}{c}\text { Formula } \\
\text { Wolght }\end{array}$} & \multirow[b]{2}{*}{ Alomic Wi. } & \multirow[b]{2}{*}{ Oxido } & \multirow[b]{2}{*}{$\begin{array}{c}\text { Oxide } \\
\text { Wolght }\end{array}$} & \multicolumn{4}{|c|}{10 Molar Na Simulant } \\
\hline & & & & & & $\begin{array}{c}\text { Targol } \\
11 \\
\end{array}$ & $\begin{array}{c}\text { Moles/L } \\
\text { Roquired } \\
\end{array}$ & $\begin{array}{c}\begin{array}{c}\text { Calclnod Solios } \\
\text { grams/ilter }\end{array} \\
\end{array}$ & $\begin{array}{c}\text { Calcined Solids } \\
\mathrm{kg} / \mathrm{gal} \\
\end{array}$ \\
\hline Alt++ & $\mathrm{Al}(\mathrm{NO} \mathrm{O}) 3 \times 9 \mathrm{H} 2 \mathrm{O}$ & 375.14 & 26.981 & $\mathrm{Al2O3}$ & 101.962 & 1.02 & 1.02 & 52.00 & 0.20 \\
\hline $\mathrm{Ca}++$ & $\mathrm{Ca}(\mathrm{NO} 3) 2 \cdot 4 \mathrm{H} 2 \mathrm{O}$ & 236.16 & 40.08 & $\mathrm{CaO}$ & 56.08 & 0.0011 & 0.0011 & 0.06 & 0.00 \\
\hline $\mathrm{Cr}++$ & $\mathrm{Cr}(\mathrm{NO}) 3 \times 9 \mathrm{H} 2 \mathrm{O}$ & 400.17 & 51.996 & $\mathrm{Cr} 2 \mathrm{O3}$ & 151.992 & 0.0087 & 0.0087 & 0.66 & 0.00 \\
\hline Fot+t+ & $\mathrm{Fe}(\mathrm{NO}) 3 \times 9 \mathrm{H} 2 \mathrm{O}$ & 104.01 & 55.847 & $\mathrm{Fe} 2 \mathrm{O} 3$ & 159.694 & 0.00077 & 0.00077 & 0.06 & 0.00 \\
\hline $\mathrm{K}+$ & $\mathrm{KOH}$ & 56.1 & 39.102 & $\mathrm{~K} 2 \mathrm{O}$ & 94.204 & 0.5 & 0.5 & 23.55 & 0.09 \\
\hline $\mathrm{Mg++}$ & $\mathrm{Mg}(\mathrm{NO}) 2^{2} 6 \mathrm{H} 2 \mathrm{O}$ & 256.41 & 24.312 & $\mathrm{MgO}$ & 40.312 & 0.001 & 0.001 & 0.04 & 0.00 \\
\hline$M n++$ & $\operatorname{Mn}(\mathrm{NO}) 2$ & 178.94 & 54.938 & $\mathrm{MnO} 2$ & 86.938 & 0.00042 & 0.00042 & 0.04 & 0.00 \\
\hline Mo+6 (a) & $\mathrm{Na} 2 \mathrm{MOO} 4^{\circ} \mathrm{H} 2 \mathrm{O}$ & 241.95 & 95.94 & $\mathrm{MoO3}$ & 143.94 & 0.017 & 0.017 & 245 & 0.01 \\
\hline $\mathrm{Nat}$ & & & 22.99 & $\mathrm{Na} 2 \mathrm{O}$ & 61.98 & 9.97 & & 295.74 & 1.12 \\
\hline$S p++(b)$ & $\mathrm{S} r \mathrm{Cl} 2$ & 158.52 & 87.62 & SiO & 103.62 & 0.017 & 0.017 & 1.76 & 0.01 \\
\hline $\operatorname{cst}(a)$ & CsNO3 & 194.91 & 1329 & Cs2O & $281: 8$ & 0.017 & 0.017 & 240 & 0.01 \\
\hline PO4_-- & $\mathrm{NaH} 2 \mathrm{PO}_{4} \cdot \mathrm{H} 2 \mathrm{O}$ & 138 & 94.98 & P2OS & 141.948 & 0.043 & 0.043 & 3.05 & 0.01 \\
\hline $103--\infty$ & NalO3 & 197.89 & 174.9 & $\mathrm{Nal}$ & 149.895 & 0.017 & 0.017 & 255 & 0.01 \\
\hline co3-- & $\mathrm{N} 22 \mathrm{CO} 3$ & 106 & 60 & -- & $--\infty$ & 0.267 & 0.267 & & \\
\hline $\mathrm{Cl}-$ & $\mathrm{NaCl}$ & 58.45 & 35.153 & $\mathrm{NaCl}$ & 58.443 & 0.16 & 0.13 & 9.35 & 0.04 \\
\hline F- & $\mathrm{NaF}$ & 42 & 19 & $\mathrm{NaF}$ & 41.99 & 0.25 & 0.25 & 10.50 & 0.04 \\
\hline so4-- & $\mathrm{Na}_{2} \mathrm{SO}_{4}$ & 14206 & 96.064 & so3 & 80.08 & 0.043 & 0.043 & 3.44 & 0.01 \\
\hline NO3- & & & 62 & --- & --- & 3.11 & & & \\
\hline NO2-. & NaNO2 & 69 & 44 & -- & $-\infty$ & 1.67 & 1,667 & & \\
\hline $\mathrm{OH}-(0)$ & $\mathrm{NaOH}$ & 40 & 17 & -- & $-\infty$ & 3.83 & 6.667 & & \\
\hline TOC & NaAEDTA $(C 10)$ & 416.2 & 12 & --- & -- & 1.35 & 0.135 & & \\
\hline TOTALS & & & & & & & & 407.65 & 1.54 \\
\hline
\end{tabular}


3. Installation of agitation and heating systems on the new feed tank.

4. Installation of a larger capacity simulant feed pump.

5. Installation of a slurry injection pump for tuyere feed of combined frit and simulant.

6. Extending the tuyere length from $30 \mathrm{~cm}$ to $120 \mathrm{~cm}$ to provide longer residence time and better mixing of the waste simulant and glassformers.

7. Fabrication of additional glass receiving containers.

8. Installation of on-line $\mathrm{SO}_{2}$ analysis equipment to complement existing $\mathrm{NO}_{2}$ and $\mathrm{CO}_{\mathrm{x}}$ systems (see Section 2.3).

9. Provision for pitot tube air velocity measurement in vertical section of the melter.

10. Fabrication of a sampling port for aerosol collection in vertical section of the melter to complement existing port downstream of quench/scrubbing system.

11. Replacement of melter refractory with corrosion resistant Ruby Refractory lining in the crucible and tuyere zones.

12. Cleanout and disposal of scrubber water inventory, and replacement by clean water.

13. Installation of an in-line waste-glassformer blender.

These modifications are being carried out during the pre-test phase and will not significantly affect the test schedule.

\subsubsection{Pre-Demonstration Trial Heats}

Three pre-demonstration tests lasting up to eight hours will be carried out before the demonstration test. The objectives of these tests are:

1. Verify operability of new and modified equipment.

2. Determine optimum method of feeding the frit and simulated waste.

3. Train the operators.

4. Verify the performance of the glass composition in the plasma melter environment. 
The schedule for these tests and the feed conditions which are anticipated are as follows:

Trial Heat\#1 (Scheduled for October 12, 1994)

1. Characterization of glass properties, composition, and volatiles retention at operating temperatures

2. Demonstration of low-NO torch operation

3. Demonstration of extended tuyere performance

4. Feed rate of approximately 4 liters/minute using the current injection system

5. Injection of both glassformers and simulant into the tuyere

6. Eight hour duration

7. 0.6 tonne of waste simulant calcined solids ( 1500 liters) to be processed

8. 1.7 tonnes of glass former required (as frit).

Trial Heat \#2 (Scheduled October 26, 1994)

1. Characterization of glass properties, composition, and volatiles retention at operating temperatures

2. Glassformers feed as $1 / 4^{\prime \prime}$ chunk with coke into top of melter (see Section 2.1)

3. Waste simulant fed into tuyere

4. Feed rate of 4 liters/minute using the current injection system

5. Startup with glass with the final glass composition in the lower portion of the cupola; 0.6 tonnes required

6. Eight hour duration

7. 0.8 tonne of waste simulant calcined solids ( 1900 liters of simulant)

8. 2.3 tonnes of glass former required (as chunk solids)

Trial Heat \#3 (Scheduled for November 9, 1994)

1. Higher throughput and longer duration system shakedown run

2. Feed rate of 6 liters/minute using new feed injection and mixing system

3. Use of more successful glassformer-simulant injection/melting strategy based on results of Trial Heats \#1 and \#2

4. Start-up testing of new offgas velocity and $\mathrm{SO}_{2}$ instrumentation 
5. Eight hours duration

6. 1.1 tonnes of waste simulant calcined solids (2650 liters of simulant) to be processed

7. 3.2 tonnes of glass former calcined solids required as frit

8. 0.6 tonnes of startup glass required (if coke is used)

Performance of Trial Heat \#1 on 10/12 depends on delivery and installation of the extended tuyere; if this component is not available by that time, Trial Heat \#2 will be carried out first.

\subsubsection{Facility Pretest Maintenance}

Before beginning the demonstration test, pre-test maintenance will be carried out on the melter. This maintenance will ensure that there is no cross-contamination between the pre-demonstration tests and the demonstration test. Included in this maintenance are the following:

1. Installation of new refractory in the crucible of the melter.

2. Installation of new refractory in the product collection spout system.

3. Draining and complete cleanout of the scrubber tank inventory, replacement with fresh water, and sampling to determine baseline conditions.

4. Cleaning and flushing of all tanks and lines associated with the feed makeup system and sampling to determine baseline conditions.

5. Calibration of the instrumentation to QA specifications as defined by Section 4.4 of the Plasma Vitrification Project Quality Plan."

'J. S. Lauer, "Plasma Vitrification Project Quality Plan," Westinghouse Science and Technology Center, September 6, 1994. 


\section{MELTER SYSTEM DESCRIPTION}

The plasma facility consists of a Plasma Melter including a plasma torch thermal source capable of $1.5 \mathrm{MW}$ output, several feed supply systems for injecting metered quantities of aqueous/slurry chemical species and glassformers, a glass product collection system, a scrubber system for separating and collecting aerosols and volatiles, and a state-of-the-art process control and data acquisition system. The plasma melter will produce 13 metric tonnes/day of a vitrified product containing glassformers and thermally processed simulated waste. The overall system is illustrated in Figure 2.1.

\subsection{FEED SYSTEM}

\subsubsection{Waste Feed System}

Two methods for feeding glassformers will be tested as part of the predemonstration test series:

1. as a powder through an auger into the tuyere along with the waste simulant, or

2. a mixture of coke and chunk glassformer through the charge door near the top of the melter shaft

In either case, the waste will be pumped to the tuyere and injected in front of the torch. The feedstock supply capabilities for the Plasma Processing Facility consist of a liquid/slurry feed system and a glassformer feed system. The current liquid/slurry feed system (Figure 2.2) will be used to feed simulated low-level waste at a rate of 4 liters/minute during tests 1 and 2 of the pre-demonstration tests. This system will then 

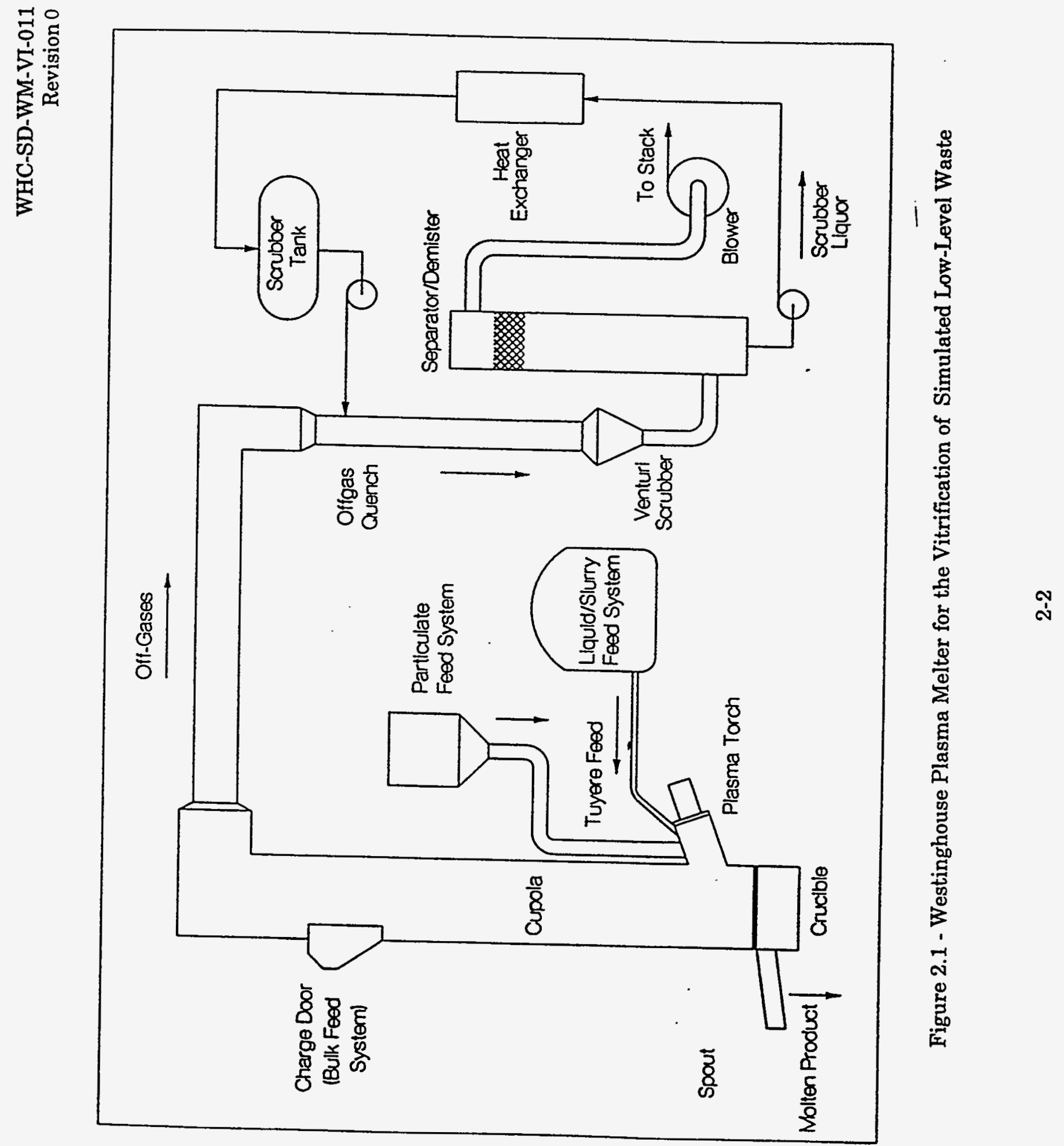


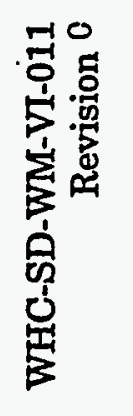


be upgraded by the addition of a larger pump and a backup pump to feed at a rate of 6 liters/minute for the third pre-demonstration test and the demonstration test. A unique primary and secondary recirculation system, in combination with a mechanical agitator, maintains feed uniformity in suspension in the holding/mixing tank and throughout the injection system to ensure that the desired chemical composition is injected into the Plasma Melter. Flowrates of liquid/slurry feeds are monitored and metered by a flowmeter (F1) combined with a metering valve. Sampling ports are strategically located at three locations the feed system for taking grab samples for analysis.

This same multiple-loop recirculation system concept was used successfully during the 1993 and 1994 plasma calcination tests, providing a uniformity of suspended solids to within a few percent over eight hours of operation. A roughing filter (approximately $0.3 \mathrm{~cm}$ polypropylene mesh) is provided to protect the feed pump and instrument ports from possible plugging by large particles. This was a major issue during the calcination tests where a much more concentrated feed slurry was being processed; occasional reversal of the feed pump was required in those tests to keep the filter backwashed and clear. With the lower feed concentration and minimal suspended solids content of the current feed, this issue is not expected to arise.

A 15,000 liter outside chemical storage and mixing tank will be installed to accommodate the anticipated volume of chemical slurry needed for the test. An immersion heater with a capacity of $25 \mathrm{~kW}$ will be utilized to maintain the Hanford lowlevel waste chemical simulant temperature at or about 25 to $30^{\circ} \mathrm{C}$ to avoid precipitation and increases in simulant viscosity due to cold weather.

\subsubsection{Glassformer Feed System}

Three configurations for vitrification will be examined during the predemonstration trial heats:

1. Injection of blended glassformer frit and waste simulant into the tuyere, with an extended tuyere design to increase the residence and mixing time of the two components in the high temperature plasma plume zone, before expansion into the open melter shaft (the same concept originally described in the proposal). 
2. Injection of blended glassformer frit and waste simulant into the tuyere, but with the melter shaft provided with a bed of granular metallurgical grade coke loaded through the charge door near the top of the melter shaft.

3. Injection of waste simulant into the tuyere, with simultaneous injection of larger particle-size glassformer material and coke through the shaft charge door.

Testing of the first two configurations is planned for Trial Heat \#1, while the third configuration will be evaluated in Trial Heat \#2. The configuration of Trial Heat \#3 will be determined pending analysis of the results of the first two tests. When glassformers are injected into the tuyere, metering occurs in a variable-speed auger feeder (equipped with a vibrator and a nitrogen purge of 2 to 5 standard liters/sec to ensure a constant and desired feed rate). Frit is then dropped into the hopper of a Moyno pump, where it is blended with the waste simulant and injected into the tuyere. In the case of glassformer top feed, frit is mixed with coke in pre-weighed barrels, and dumped into the top of the melter.

Each configuration provides both benefits and raises potential operational issues. The first concept is the simplest, requiring no additional feed material (i.e. coke), and minimizing both solid handling problems and offgas generation. The offgas flowrates can be further reduced by use of steam for the shroud gas, dropping noncondensible offgas volumes by as much as $75 \%$ as compared to use of air in the shroud (see Table 2.1 below). However, formation of glass depends on chemical affinity between calcined sodium compounds $\left(\mathrm{Na}_{2} \mathrm{O}\right.$ and $\mathrm{NaOH}$ ) and glassformer species (such as $\mathrm{SiO}_{2}$ and $\mathrm{B}_{2} \mathrm{O}_{3}$ ), which must mix and combine during the short residence time in the tuyere. If sufficient mixing and recombination does not occur, loss of volatile sodium and other species (e.g. cesium) may result.

Use of a coke bed is a proven technology at WSTC for vitrification of a wide variety of materials (simulated landfill, bulk soil, clay, etc.), having been demonstrated at tonnes-per-hour throughput using a combination of plasma heating and coke combustion. The presence of coke acts as a scrubbing medium. Passage of aerosolized material through the coke bed typically results in removal of the great majority of entrained particles and condensed aerosols through attachment to sticky colse surfaces, while the temperature gradient that develops between the top and bottom of the coke 
bed allows for condensation of volatile salts. Since the coke bed is continuously consumed from the bottom, scrubbed salts and aerosols are conveyed back into the melt zone.

Injection of both waste and glassformers below a coke bed therefore provides a much lower probable volatile sodium loss. Issues also arise from use of such a coke bed. Sodium salts may not be sufficiently attached to coke particles since no chemical affinity exists between them, so that the scrubbing action may not be as efficient as expected from previous processing of low-sodium materials. Condensed species such as $\mathrm{NaOH}$ may reevaporate as they enter the hotter regions lower in the shaft, causing reflux and accumulation in an intermediate temperature zone part way up the shaft; sufficient accumulation could lead to bridging and clogging of the shaft.

Coke may also interact with the chemistry of the glassformers and the waste. Because of reducing conditions resulting from the presence of carbon, certain species in the waste which are normally highly volatile during vitrification (notably $\mathrm{RuO}_{4}$ and $\left.\mathrm{TC}_{2} \mathrm{O}_{7}\right)$ will be reduced to less volatile valence states $\left(\mathrm{RuO}_{2}\right.$ and $\left.\mathrm{TcO}_{2}\right)$, and will be incorporated into the glass. This is of particular benefit for technetium, which is difficult to incorporate into LLW glass. Transition metals such as iron and nickel may also be reduced to the metallic form. Removed as a separate molten metal stream (if the temperature is sufficiently high), elimination of low-solubility components such as nickel oxide from the glass mixture may improve waste loading for certain LLW compositions.

The potential also exists for coke to reduce other species such as boron (to form $\mathrm{B}_{4} \mathrm{C}$ ) or alkali metals (to form metal vapor); loss of either would increase glass melt viscosity. Thermodynamic studies using the CET89 equilibrium thermodynamic simulator with the proprietary Westinghouse CHEMEQ thermochemical database have evaluated the possibility of undesirable carbon reduction reactions. Results indicate that under conditions proposed for the current test program, boron will not be reduced, and that alkali metal vapor formation is negligible at all temperatures at or below about $1200^{\circ} \mathrm{C}$.

Interaction of coke with water from the waste is also an issue. Hot carbon will react with steam, reforming to produce carbon monoxide and hydrogen. Although potentially creating a flammability or explosion hazard if not properly dealt with, both 
are routinely produced in commercial Plasma Melter operations, and are combusted in the afterburner section. However, the large quantity of water injection will produce unusually large quantities of $\mathrm{CO}$, increasing coke consumption, lowering bed temperatures (due to the endothermicity of the reforming reaction), and generating higher than usual temperatures in the afterburner section. If a coke bed is used, noncondensible offgas volumes can be reduced somewhat (about 10\%) by substitution of steam as the shroud gas, but the impact is much less than with an empty shaft; a comparison of total offgas generation from the various configurations is shown in Table 2.1. The degree of reforming of the injected steam is difficult to predict without detailed kinetic modeling; Table 2.1 assumes complete reforming of all water with nominal flowrates of $120 \mathrm{scfm}$ (3.4 standard $\mathrm{m}^{3} / \mathrm{min}$ ) torch air, $350 \mathrm{scfm}(9.9 \mathrm{~m} / \mathrm{min}$ ) shroud gas, and $1 \mathrm{gpm}$ (3.8 $\mathrm{l} / \mathrm{min})$ simulant feed.

In the third conceptual approach, the scrubbing efficiency of the bed is increased by adding the glassformers premixed with coke at the top of the shaft. The bed thus contains material chemically active towards sodium and sodium salts, and should provide optimal scrubbing action for volatile salts and minimal scrubber recycle requirements. The glassformers are conveyed into the melt zone by the downward motion of the coke bed as it is consumed; the ratio of coke to glassformers is predetermined to provide the proper glassformer addition rate to balance the waste feed. The rate of coke consumption can in turn be controlled by adjusting the air feed in the tuyere, and by increasing or decreasing the plasma torch power. These control options are guided by analysis of the offgas; the $\mathrm{CO}, \mathrm{CO}_{2}$, and $\mathrm{H}_{2}$ content of the offgas combined with the air and water injection rates allow the rate of coke combustion to be determined.

Although the more indirect control mechanism described above is believed to be practical, other issues exist in this configuration. Since glassformers are present in the coke bed, partial melting is expected as the material nears the melt zone. Softening and slumping may lead to agglomeration of the coke bed and channeling of the upward gas flow or plugging of the shaft. This situation is not unlike that encountered in previous WSTC coke-bed vitrification experience, however; pressure drop diagnostics exist along 
Table 2.1 - Comparative Offgas Generation from Various Vitrification Configurations

(All flowrates in standard $\mathrm{m}^{3} / \mathrm{min} ; \mathrm{N} / \mathrm{C}=$ Non-Condensible Offgas)

\begin{tabular}{|c|c|c|c|c|c|}
\hline & $3.4 \mathrm{~m}^{3} / \mathrm{min}$ & $9.9 \mathrm{~m} / \mathrm{min}$ & $3.8 \mathrm{l} / \mathrm{min}$ & & Stack* \\
\hline Configuration & Torch Gas & Shroud Gas & Waste & Shaft Gas & Exhaust \\
\hline Torch Gas = Air & $2.7 \mathrm{~N}_{2}$ & $7.8 \mathrm{~N}_{2}$ & $0.2 \mathrm{~N}_{2}$ & $10.7 \mathrm{~N}_{2}$ & $10.7 \mathrm{~N}_{2}$ \\
\hline Shroud Gas = Air & $0.7 \mathrm{O}_{2}$ & $2.1 . \mathrm{O}_{2}$ & $0.3 \mathrm{O}_{2}$ & $3.1 \mathrm{O}_{2}$ & $3.1 \mathrm{O}_{2}$ \\
\hline \multirow[t]{3}{*}{ Empty Shaft } & & & $0.1 \mathrm{CO}_{2}$ & $0.1 \mathrm{CO}_{2}$ & $0.1 \mathrm{CO}_{2}$ \\
\hline & & & $3.5 \mathrm{H}_{2} \mathrm{O}$ & $3.5 \mathrm{H}_{2} \mathrm{O}$ & $3.5 \mathrm{H}_{2} \mathrm{O}$ \\
\hline & & & & & $(14.0 \mathrm{~N} / \mathrm{C})$ \\
\hline Torch Gas = Air & $2.7 \mathrm{~N}_{2}$ & $9.9 \mathrm{H}_{2} \mathrm{O}$ & $0.2 \mathrm{~N}_{3}$ & $2.9 \mathrm{~N}_{2}$ & $2.9 \mathrm{~N}_{2}$ \\
\hline Shroud Gas = Steam & $0.7 \mathrm{O}_{2}$ & & $0.3 \mathrm{O}_{2}$ & $1.0 \mathrm{O}_{2}$ & $1.0 \mathrm{O}_{2}$ \\
\hline \multirow[t]{3}{*}{ Empty Shaft } & & & $0.1 \mathrm{CO}_{2}$ & $0.1 \mathrm{CO}_{2}$ & $0.1 \mathrm{CO}_{2}$ \\
\hline & & & $3.5 \mathrm{H}_{2} \mathrm{O}$ & $13.4 \mathrm{H}_{2} \mathrm{O}$ & $13.4 \mathrm{H}_{2} \mathrm{O}$ \\
\hline & & & & & $(4.1 \mathrm{~N} / \mathrm{C})$ \\
\hline Torch Gas = Air & $2.7 \mathrm{~N}_{2}$ & $7.8 \mathrm{~N}_{2}$ & $0.2 \mathrm{~N}_{2}$ & $10.7 \mathrm{~N}_{2}$ & $10.7 \mathrm{~N}_{2}$ \\
\hline Shroud Gas = Air & $0.7 \mathrm{O}_{2}$ & $2.1 \mathrm{O}_{2}$ & $0.3 \mathrm{O}_{2}$ & $10.0 \mathrm{CO}$ & $10.0 \mathrm{CO}_{2}$ \\
\hline \multirow[t]{2}{*}{ Coke-Filled Shaft } & & & $0.1 \mathrm{CO}_{2}$ & $3.5 \mathrm{H}_{2}$ & $3.5 \mathrm{H}_{2} \mathrm{O}$ \\
\hline & & & $3.5 \mathrm{H}_{2} \mathrm{O}$ & & $(20.7 \mathrm{~N} / \mathrm{C})$ \\
\hline Torch Gas = Air & $2.7 \mathrm{~N}_{2}$ & $9.9 \mathrm{H}_{2} \mathrm{O}$ & $0.2 \mathrm{~N}_{2}$ & $2.9 \mathrm{~N}_{2}$ & $2.9 \mathrm{~N}_{2}$ \\
\hline Shroud Gas = Steam & $0.7 \mathrm{O}_{2}$ & & $0.3 \mathrm{O}_{2}$ & $15.8 \mathrm{CO}$ & $15.8 \mathrm{CO}_{2}$ \\
\hline \multirow[t]{2}{*}{ Coke-Filled Shaft } & & & $0.1 \mathrm{CO}_{2}$ & $13.4 \mathrm{H}_{2}$ & $13.4 \mathrm{H}_{2} \mathrm{O}$ \\
\hline & & & $3.5 \mathrm{H}_{2} \mathrm{O}$ & & $(18.7 \mathrm{~N} / \mathrm{C})$ \\
\hline
\end{tabular}

* Offgas from coke configurations pass through afterburner between shaft and stack. No condensation of water in scrubbing system assumed. 
the length of the bed which will provide warning of developing blockages, which can generally be dealt with by proper adjustment of torch power and air flow control.

The issue has also been raised concerning the safety of carbon and unreacted nitrates forming possibly explosive mixtures. Although carbon can react in the presence of nitrates to form exothermic mixtures, this process is not expected in the plasma melter. As seen in prior testing for Westinghouse Hanford, nitrate destruction efficiencies in excess of $95 \%$ were observed using the short tuyere and operating temperatures as low as $600^{\circ} \mathrm{C} .^{5}$ With the longer tuyere (more than four times the residence time in the plasma plume) and an $1150^{\circ} \mathrm{C}$ crucible temperature, little nitrate is expected to survive long enough to encounter carbon. If exothermic reaction of the remaining nitrate with the coke bed does occur, this will take place in the hottest portions of the bed and simply contribute to the melting process in the crucible. It should be noted that previous WSTC testing has been carried out of plasma destruction of $\mathrm{NaNO}_{3}$ solutions in the presence of carbon, with no evidence of uncontrolled exotherms. 6

\subsubsection{New and Existing Equipment}

Most of the equipment used in the feed system is already installed at the Plasma Center. The major pieces of new equipment are a larger waste simulant feed pump and backup pump, a longer tuyere, a Moyno pump for tuyere injection and a larger feed tank with associated agitation and heating. The existing feed control system and piping and instrumentation will be duplicated for the new tank. The list of new and existing equipment is itemized in Table 2.2. The longer tuyere is especially necessary to increase the residence time of the waste and glass-formers to allow reaction of the sodium with the silica, reducing the volatility of the sodium. The new tank increases the simulant storage capacity to 15,000 liters, and is fabricated from caustic-resistant fiberglass-epoxy composite, capable of withstanding temperatures up to $120^{\circ} \mathrm{C}$ should

'C. H. Delegard et al., "Calcination/Dissolution Process Development 1994," Westinghouse Hanford Co., WHC-SP-1093, Rev. 0, Appendix A, June, 1994. "E. A. Pantier, "Alkali Nitrate Decomposition Using Plasma Technology," WSTC Report 85-2B6-ROCKY-R1, January 15, 1985. 
Table 2.2 - Table of Existing and New Feed System Equipment

$\begin{array}{cc}\text { COMPONENT } & \text { EXISTING SYSTEM } \\ \text { Feed Tank } & 3800 \text { liter polyethelyene } \\ \text { Tank Heater } & \text { None } \\ \text { Pump } & 550 \text { lpm double-diaphragm } \\ \text { Agitator } & 10 \mathrm{~cm} \text { impeller } \\ \text { Piping Network } & 1-5 \mathrm{~cm} \text { PVC and iron } \\ \text { Glass Former Feed } & \begin{array}{c}\text { Pneumatic-assist, gravity } \\ \text { feed; auger-metered }\end{array} \\ \text { Glassformer - } & \text { None } \\ \text { Waste Blender } & \end{array}$

NEW SYSTEM
15000 liter fiberglass
$25 \mathrm{~kW}$ immersion heater
$8001 \mathrm{pm}$ double-diaphragm
$15 \mathrm{~cm}$ impeller
Same, plumbed for new tank
Use existing system
Moyno injection pump


heating of the simulant be required (the original polyethylene feed tank was limited to $60^{\circ} \mathrm{C}$ operating temperature and 3,800 liters).

The waste simulant will be prepared by pumping the material as supplied by Hanford into the Waste Feed Tank. This material will be heated if necessary to about 25 to $30^{\circ} \mathrm{C}$ to improve its handling characteristics. After mixing, the waste simulant will be sampled and the percent solids tested against the feed specification to verify that no solids separation and settling has occurred.

\subsection{PILOT SCALE MELTER SYSTEM}

The Plasma Melter is a vertical shaft design with a height of 6.70 meters and an outer shell diameter of 1.22 meters, refractory lined to provide a 0.76 meter inner diameter. The shaft is lined with a high-alumina (91\%) refractory material which has shown good resistance to vitreous slag materials in past melter testing. A refractory lined crucible (Figure 2.3) mounts to the bottom of the vertical shaft with a bolted flange for easy assembly and disassembly. The crucible refractory lining is an aluminachromia (ruby) ceramic material capable of containing alkaline reactants at temperatures of approximately $1400^{\circ} \mathrm{C}$ with little or no degradation. A very similar refractory composition is used in the Savannah River DWPF high-level waste vitrification facility. A tap hole at the bottom of the crucible is integrated with a heated spout assembly to provide a flow path for molten, vitrified waste glass. The vitrified product will be collected in carbon steel mold boxes (107 cm x $103 \mathrm{~cm} \times 61 \mathrm{~cm}$ deep) supported by sand-lined steel mold boxes and mounted on rails for easy removal from the Plasma Melter.

The melting facility is well instrumented with temperature, pressure, and flow means for characterizing performance, as well as comprehensive on-line process gas analysis (see Figure 2.4). A production scale Westinghouse Marc-11 Plasma Torch (see Figure 2.5) supplies the thermal energy to the Plasma Melter. The torch is rated at $2000 \mathrm{~kW}$ input power with an electrical-to-thermal efficiency of approximately $87 \%$. The torch design utilizes a pair of cylindrical, water cooled electrodes to generate a dc arc, which is rotated by an electric field. Process gas is injected through the cylindrical electrode gap at typical flowrates of 3 to 4 standard cubic meters per minute (100-150 scfm). The superheated process gas is mixed with 7 to 10 standard cubic meters per 
heating of the simulant be required (the original polyethylene feed tank was limited to $60^{\circ} \mathrm{C}$ operating temperature and 3,800 liters).

The waste simulant will be prepared by pumping the material as supplied by Hanford into the Waste Feed Tank. This material will be heated if necessary to about 25 to $30^{\circ} \mathrm{C}$ to improve its handling characteristics. After mixing, the waste simulant will be sampled and the percent solids tested against the feed specification to verify that no solids separation and settling has occurred.

\subsection{PILOT SCALE MELTER SYSTEM}

The Plasma Melter is a vertical shaft design with a height of 6.70 meters and an outer shell diameter of 1.22 meters, refractory lined to provide a 0.76 meter inner diameter. The shaft is lined with a high-alumina (91\%) refractory material which has shown good resistance to vitreous slag materials in past melter testing. A refractory lined crucible (Figure 2.3) mounts to the bottom of the vertical shaft with a bolted flange for easy assembly and disassembly. The crucible refractory lining is an alumina-chromia (ruby) ceramic material capable of containing alkaline reactants at temperatures of approximately $1400^{\circ} \mathrm{C}$ with little or no degradation. A very similar refractory composition is used in the Savannah River DWPF high-level waste vitrification facility. A tap hole at the bottom of the crucible is integrated with a heated spout assembly to provide a flow path for molten, vitrified waste glass. The vitrified product will be collected in carbon steel mold boxes ( $107 \mathrm{~cm} \mathrm{x}$ $103 \mathrm{~cm} \times 61 \mathrm{~cm}$ deep) supported by sand-lined steel mold boxes and mounted on rails for easy removal from the Plasma Melter.

The melting facility is well instrumented with temperature, pressure, and flow means for characterizing performance, as well as comprehensive on-line process gas analysis (see Figure 2.4). A production scale Westinghouse Marc-11 Plasma Torch (see Figure 2.5) supplies the thermal energy to the Plasma Melter. The torch is rated at $2000 \mathrm{~kW}$ input power with an electrical-to-thermal efficiency of approximately $87 \%$. The torch design utilizes a pair of cylindrical, water cooled electrodes to generate a $\mathrm{dc}$ arc, which is rotated by an electric field. Process gas is 
injected through the cylindrical electrode gap at typical flowrates of 3 to 4 standard cubic meters per minute (100-150 scfm). The superheated process gas is mixed with 7 to 10 standard cubic meters per minute $(250-350 \mathrm{scfm})$ of shroud gas at the torch nozzle to prevent thermal damage to the Plasma Melter and to provide increased gas turbulence for more efficient distribution of thermal energy. In addition $0.7 \mathrm{~m}^{3}$ of $\mathrm{N}_{2} / \mathrm{O}_{2} / \mathrm{CO}_{2}$ and $3.5 \mathrm{~m}^{3} / \mathrm{min}$ of steam are generated from calcination of the waste at $3.8 \mathrm{liters} / \mathrm{min}$ (1.0 $\mathrm{gpm}$ ). The torch is also heavily instrumented with temperature, pressure, and flow sensors to accurately characterize its performance (see Figure 2.6).

Although a large total gas throughput by the standards of joule heated glass melting technology, the offgas volume is not unmanageable. Scaling up to a 100 tonne/day waste processing facility as shown in Table 2.3 would increase the total offgas generation to approximately $160 \mathrm{~m}^{3} / \mathrm{min}$ of noncondensibles. This may be compared to the current offgas volume of the Idaho National Engineering Laboratory high-level waste calciner of approximately $62 \mathrm{~m} / \mathrm{min}$ (2200 scfm), which is processed routinely. ${ }^{7}$ Additional means are also available to reduce the production of noncondensables, including use of steam as the shroud gas which (as seen in Table 2.3) reduced noncondensible offgas production to less than $50 \mathrm{~m}^{3} / \mathrm{min}$. Although not experimentally demonstrated to date, there is no technical reason why condensable steam could not be used for this purpose. Use of steam shroud cooling is suggested for possible Phase 2 demonstration.

The primary process control parameter to control torch power will be the melt temperature which will be taken by immersion thermocouples in the melt zone (T17) and at the pour spout (T18). Additional thermal data will be derived from thermocouples imbedded in the refractory of the crucible, close to the inner surface in both the crucible and tap hole. Use of multiple temperature measurements to ascertain the bulk melt temperature allows any spatial gradients to be averaged in establishing a single nominal glass temperature. If melt temperature decreases and

\footnotetext{
${ }^{7}$ Ref: P. Winston, Westinghouse Idaho Nuclear Company, Personal Communication,
} May 16, 1994. 


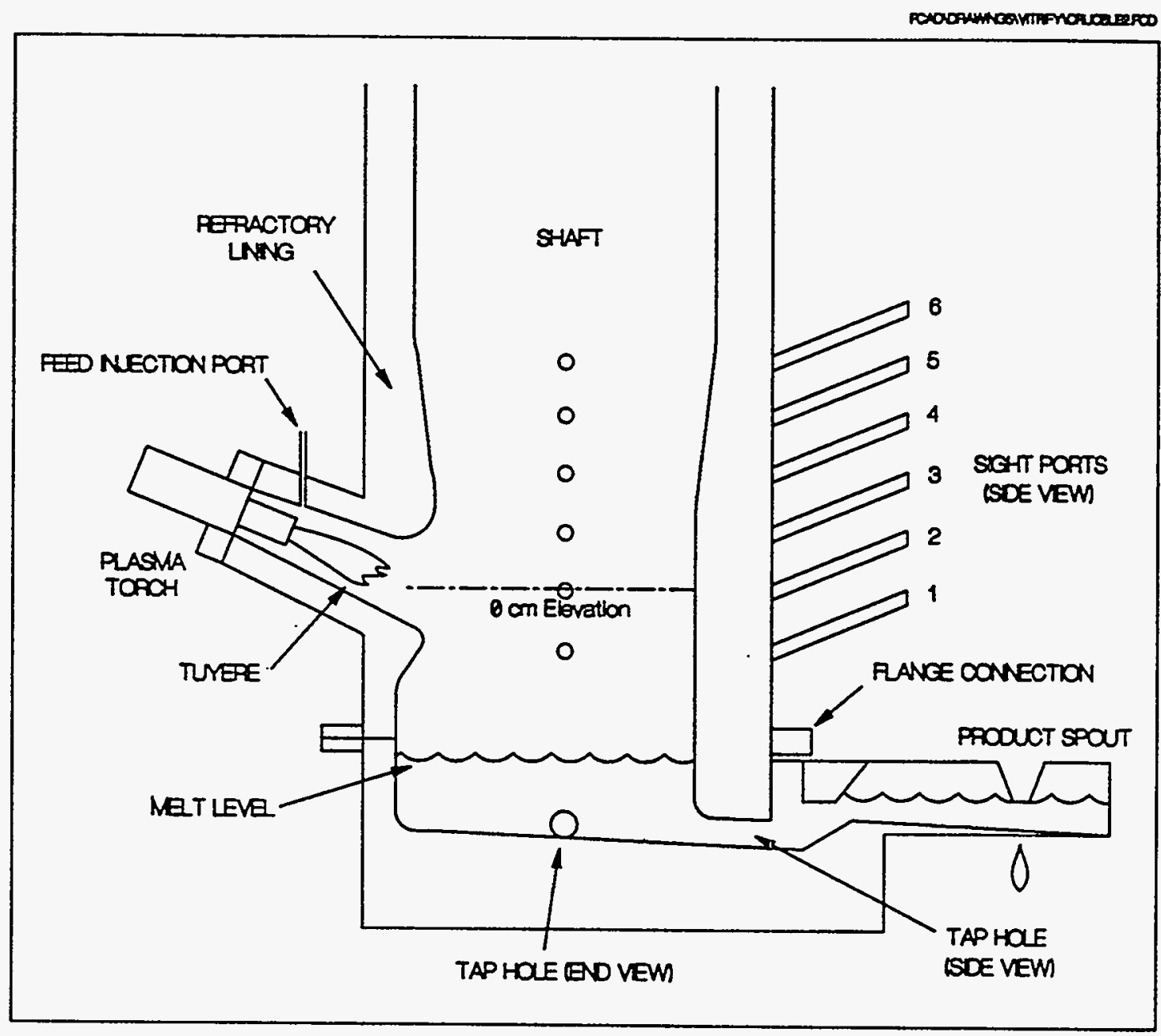

Figure 2.3 - Diagram of the Crucible Portion of the 14 ton per day Plasma Melter 


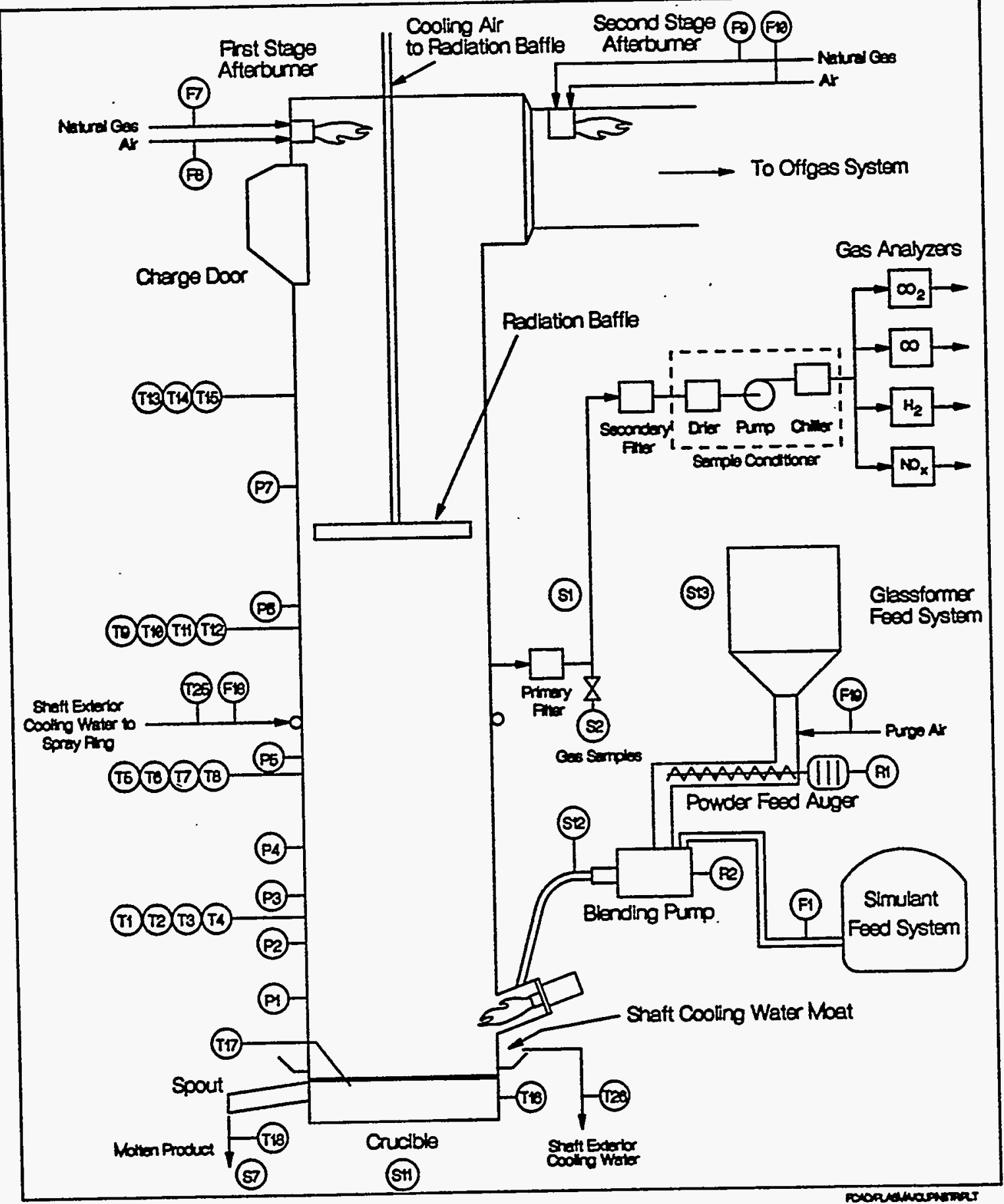

Figure 2.4 - Schematic of Plasma Melter System Instrumentation. 


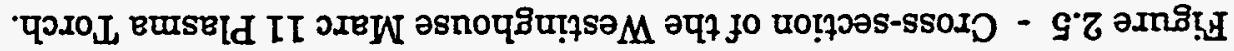

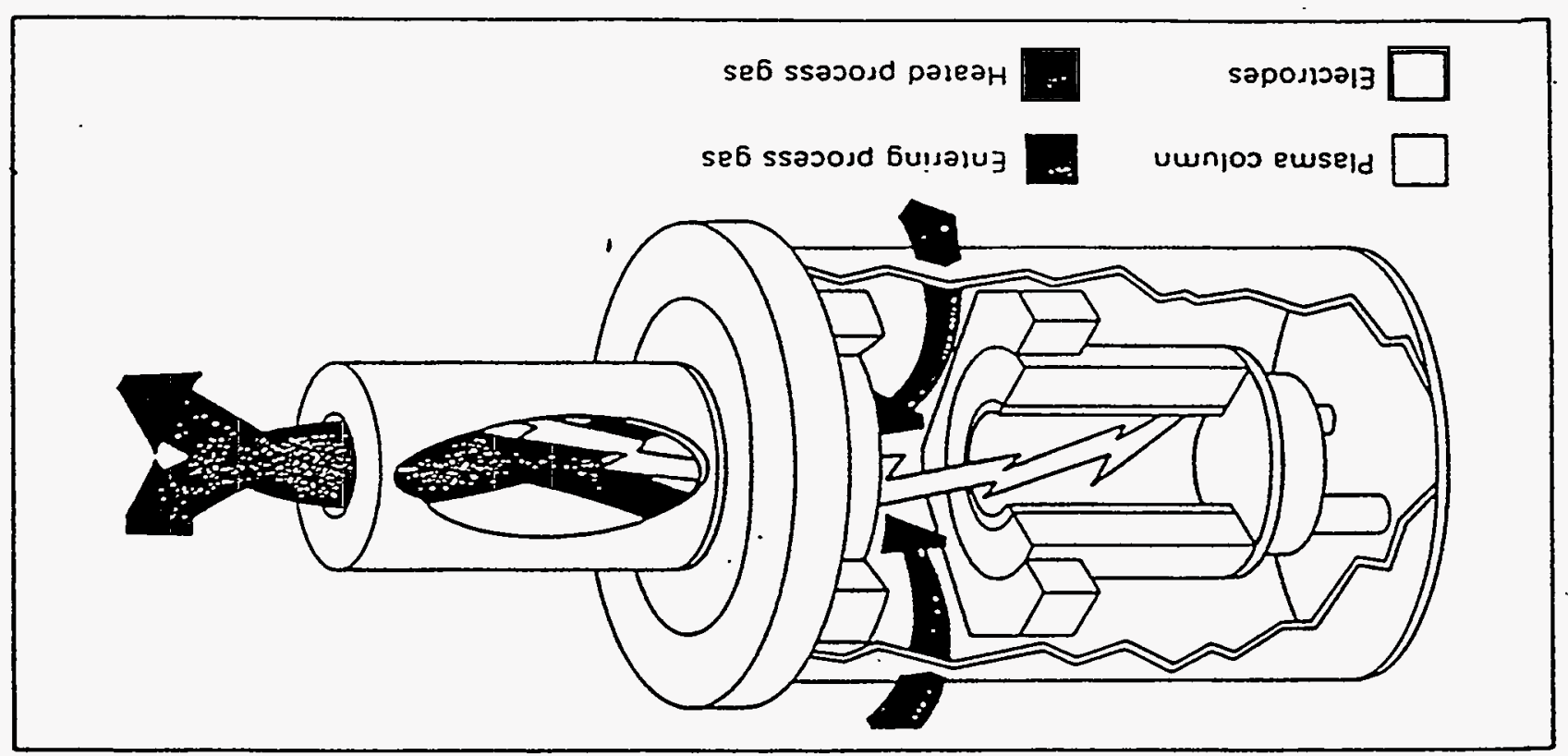



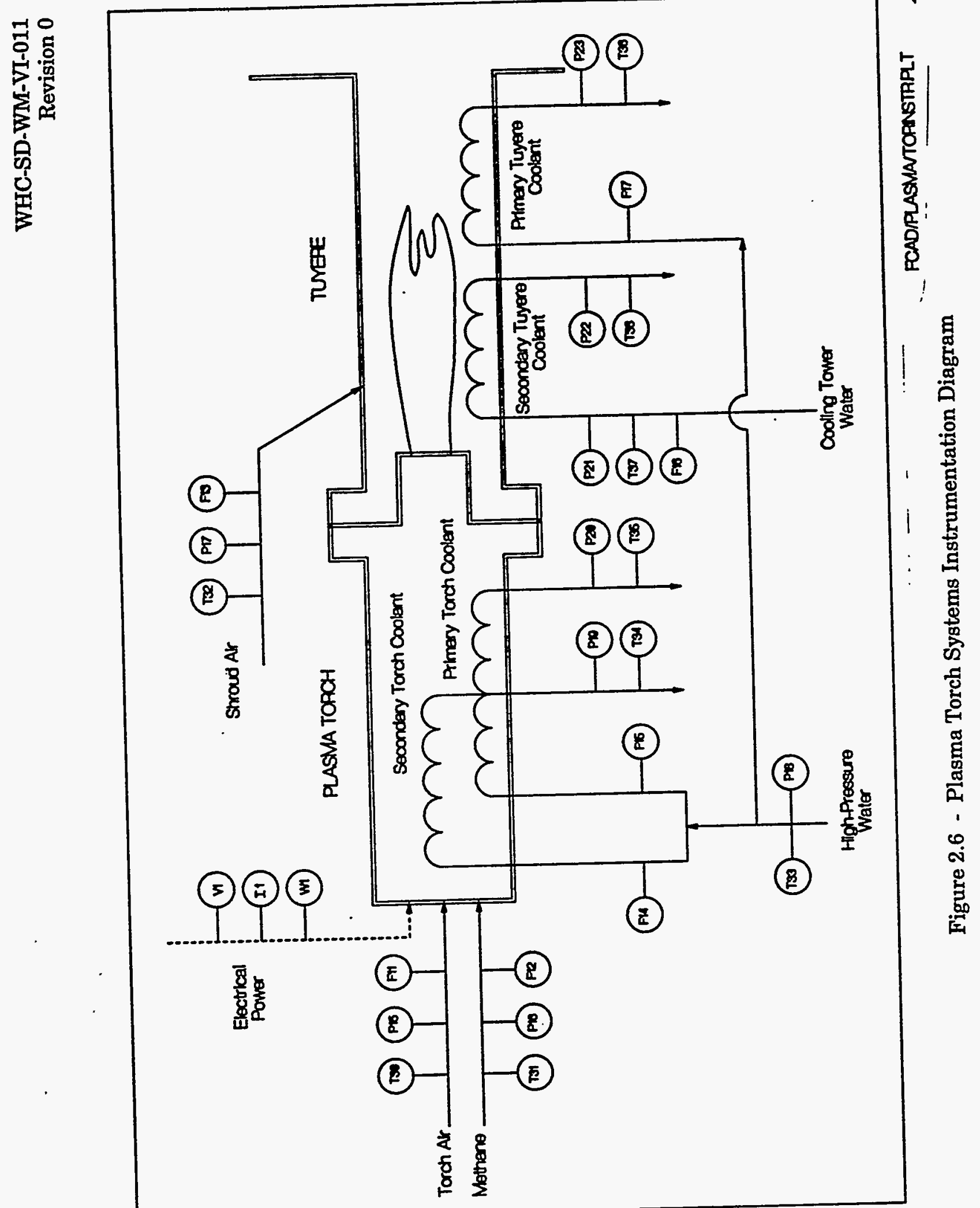

ำ 


\section{Table 2.3 - Offgas Generation from Plasma Vitrification}

Basis - $100 \mathrm{Mg} /$ day glass production

Offgas scaled 11.3x from Pilot Test $6.2 \mathrm{~kg} / \mathrm{min}$ glass production rate ( $3.8 \mathrm{lpm}$ waste) as shown in Table 2.1.

Offgas Source

Torch Air

Shroud Gas

(1) Air

(2) Steam

Waste Water

Calcination Gases

Total

(1) Air Shroud Gas

(2) Steam Shroud Gas
Std. $\mathrm{m}^{3 / m i n}$

Noncondensibles

38

111

0

0

8

157

46
Sta. $\mathrm{m}^{3} / \mathrm{min}$

Condensibles

\section{0}

0

111

26

13

39

150 
the molten product viscosity increases, the arc current to the torch will be increased at the discretion of the torch operator which will increase the output power of the torch and consequently the melt temperature. The feed rate of the glassformer powder (if fed through the tuyere) will be held constant by the feed auger. The feed rate of waste simulant will be held constant by a control loop through the feed control valve.

The product glass will be continuously poured through the spout into carbon steel mold boxes. The product glass will be sampled by taking a sample into a 2 liter steel can or onto flat steel plates from the pouring glass product.

As noted above, residues from previous tests will be removed from the melter by removing the crucible and physically removing any residue from the crucible and the vertical shaft. Refractory will be replaced as required. In any case, the predemonstration condition of the refractory (i.e., the inside radius) will be noted at various locations to allow life and maintenance requirements to be estimated. The greatest refractory wear is anticipated in the crucible area and tuyere. Accurate before and after dimensions of the crucible are difficult to obtain; loss of ruby refractory from the crucible will be monitored by material balance on chromium and aluminum in the product. In the tuyere where the less resistant precast alumina refractory is used, the geometry is well defined and monitoring of refractory loss will be done by measuring physical dimensions. In addition, other high wear points to be measured are the tap hole and the pour spout.

\subsection{OFFGAS SYSTEM}

The off-gas handling system (see Figure 2.7) consists of an afterburner, a prequench, a venturi scrubber, a separator/demister, a heat exchanger, a scrubber reservoir tank, and a blower exhaust. If coke is used in the process, the afterburner system (see Figure 2.4) will combust the $\mathrm{H}_{2}$ and $\mathrm{CO}$ to $\mathrm{H}_{2} \mathrm{O}$ and $\mathrm{CO}_{2}$. The venturi high efficiency scrubber removes heavy particulates from the exhaust stream. The separator/demister removes additional solid particulates and aerosols and thoroughly scrubs the exhaust stream, capturing water soluble off-gas products and sending them to a 15,000 liter scrubber tank. Environmentally acceptable $\mathrm{N}_{2} / \mathrm{O}_{2} / \mathrm{CO}_{2}$ off-gas is ejected by the blower through an exhaust stack. The heat exchanger in the scrubber tank. removes thermal energy absorbed from the off-gas stream by the scrubber system 


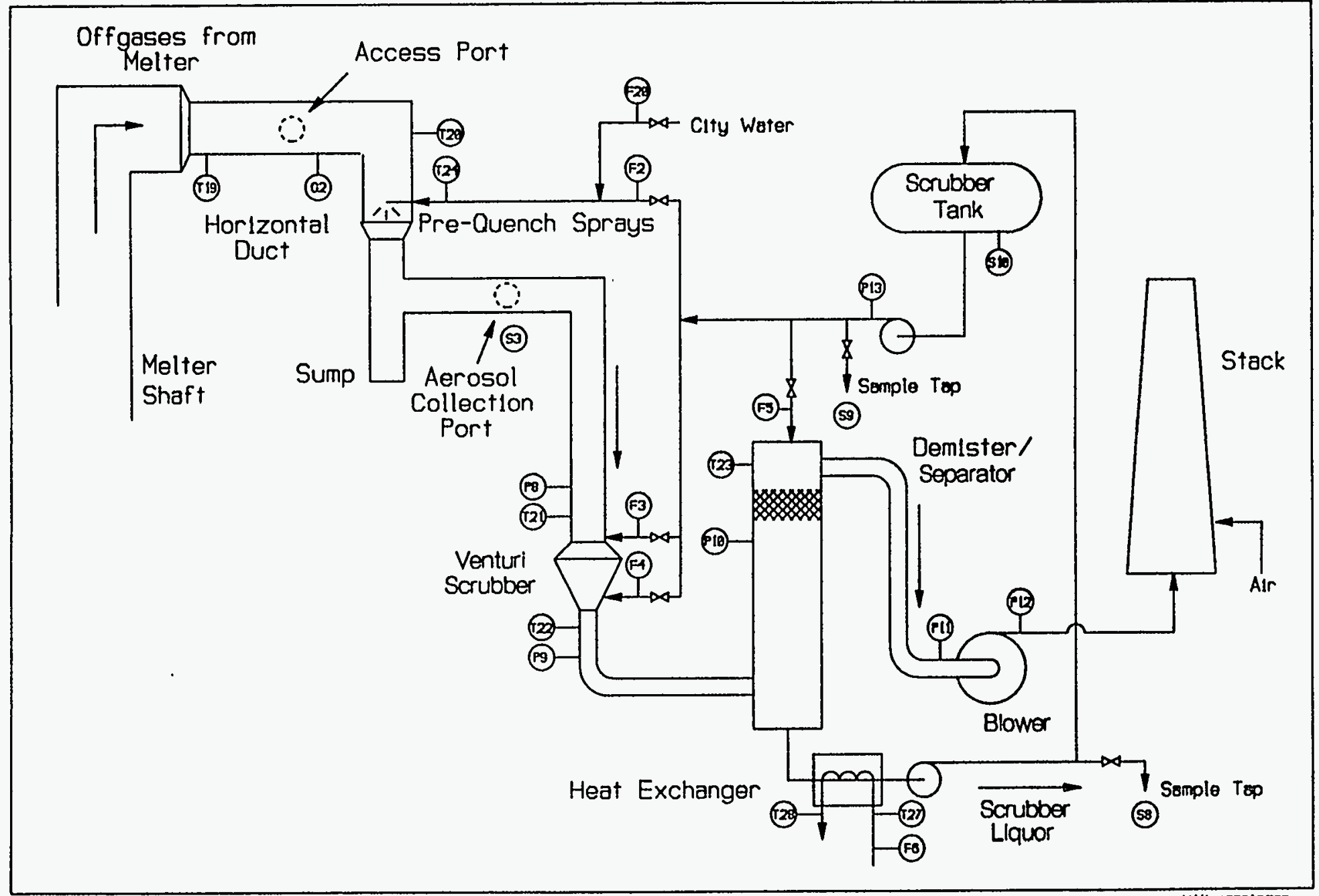

nASMVOFALFCD

Figure 2.7 - Sampling and Process Measurement Locations in Offgas System 
and prevents excessive temperature rise in the scrubber reservoir tank. The scrubber tank recirculating system has two sampling ports (S8 and S9) for removing grab samples for analysis.

Continuous on-line sampling of shaft gases is done for $\mathrm{CO}_{2}, \mathrm{CO}, \mathrm{H}_{2}$, and $\mathrm{NO}_{\mathbf{x}}$. The gases are extracted from the shaft by a small pump, processed by a sample conditioner to cool and dry the gases; and then passed through four analyzers. Manufacturer's specifications on the sample conditioner indicate that less than 5\% loss of $\mathrm{NO}_{x}$ should be expected during the drying and cooling process.

Note that efforts to obtain an on-line $\mathrm{SO}_{2} / \mathrm{SO}_{x}$ analyzer for this application were not successful, due to the unavailability of instrumentation capable of reading the low expected level of sulfur oxides (less than $300 \mathrm{ppm}$ ) in the presence of water vapor. Typical $\mathrm{SO}_{2}$ analyzers operate on infrared absorption, and are extremely sensitive to interference by $\mathrm{H}_{2} \mathrm{O}$ ( 1 ppm of $\mathrm{H}_{2} \mathrm{O}$ creates absorbance equivalent to 150 $\left.\mathrm{ppm} \cdot \mathrm{SO}_{2}\right){ }^{8}$ Several instrument suppliers were contacted with requests for quotes; none were willing to quote with the exception of one supplier of gas chromatographic equipment, for which delivery was four months. Sulfur balancing will therefore be done by analysis of the products and scrubber water, rather than direct analysis of the offgases.

Similar instrumentation difficulties were encountered in obtaining gas flowrate or velocity monitoring in the duct system. Only one instrument supplier (Annubar) was identified who could provide instrumentation capable of measuring flow velocity at the high temperatures existing in the horizontal duct. However, upon more detailed study of the specifications, the pressure drop existing in the Annubar instrument would be too low to measure. No direct effort will therefore be made to measure offgas flowrate. The total offgas flow may be computed, however, by measuring the argon content of the offgas. All argon enters the system from the torch and shroud air (at known concentration and flowrate), so that the total offgas flow at a known argon partial pressure may then be computed.

\footnotetext{
'J. Wadas, Wadas Instrument Services, Personal Communication to the Author, August 29, 1994.
} 
Monitoring points are indicated in Figures 2.4 and 2.7. The flow rates and temperatures of the gases and scrubber liquids will be monitored and recorded via datalogger. Pressures in the gas train will also be monitored and manually recorded. The gas sampling points are also indicated on Figure 2.4. These ports will be used to take samples for the on-line non-condensable gas composition equipment. EPA Method 5 sampling will be conducted on the hot sub-saturated gas downstream of the pre-quench spray at sample location S3 to determine the amount of aerosolentrained particles. Although the access port in the horizontal duct would provide aerosol sampling upstream of quench (and therefore results more representative of conditions in the melter shaft), the temperatures here are too high to allow Method 5 sampling. It is anticipated that the primary effect of the prequench spray will be to encourage agglomeration of aerosols and condensation of salt vapors. To avoid contamination of aerosol samples with dissolved material in the recirculated scrubber water, city water will be substituted in the pre-quench spray during aerosol sampling. Although this water also contains some dissolved material, its composition is constant and can be corrected for in the interpretation of the Method 5 analyses.

\subsection{SECONDARY STREAMS}

The only secondary streams in this process are the water cooling streams for the plasma torch, tuyere, melter shaft and scrubber water heat exchangers. The flow rate and inlet and outlet temperatures will be monitored for each by the data acquisition system (see Table 3.1 below) to allow the overall energy balance for the process to be determined.

\subsection{FLOWSHEET}

No chemical pretreatment of the simulant is anticipated at this time. This may change, however, depending on the results of the predemonstration tests. For instance, if the first pre-demonstration test indicates that $20 \%$ of the sodium in the feed is carried over, than an equivalent amount of sodium hydroxide may be added 
to the waste simulant in the feed tank. Sodium hydroxide carryover is the most likely material to be carried over from the waste due to its relatively low boiling point $\left(1390^{\circ} \mathrm{C}\right)$. Such changes will not be identified until after completion of the predemonstration tests and this test plan will then be amended to reflect these changes.

The composition and target characteristics of SRTC Composition \#4 glassformers are outlined in Section 1.3.2 above. When mixed with the waste simulant composition as given in Table 1.1, a target product glass with the composition shown in Table 2.4 is expected. This glass is designed for a waste loading of $25 \%$, a viscosity at $1150^{\circ} \mathrm{C}$ of $<100$ poise, no second phases, and leaching performance (based on sodium leachability) exceeding that of the reference EA glass. Performance based on an abbreviated 3-day PCT is shown in Figure 2.8, and is seen to exhibit leaching rates lower than EA glass by an order of magnitude. Note that some alkali in the form of $\mathrm{Li}_{2} \mathrm{O}$ is present in the glassformer to lower the melting point and facilitate preparation of the premelted frit. It is anticipated that Phase 2 testing will include a demonstration with virgin chemical glassformers to reduce cost. Using virgin materials, a modified glassformer composition with little or no alkali is anticipated.

The glass residence time in the process will be determined from the following data:

1. weighing the amount of glass produced over the entire demonstration $\left(W_{q}\right)$

2. the specific gravity of the molten glass $\left(G_{z}\right)$

3. the production time $(t)$ during the demonstration (time during which the product glass was pouring)

4. the volume of the crucible (v).

\footnotetext{
- "Statement of Work for Evaluation of Melter System Technologies for Vitrification of HighSodium Content Low-Level Radioactive Liquid Wastes." WHC-SD-WM-RD-044, Revision 0, Westinghouse Hanford Company, February 15, 1994.
} 
WHC-SD-WM-VI-011

Revision 0

Table 2.4 - Predicted Final Glass Composition

\begin{tabular}{|c|c|c|c|c|c|c|c|}
\hline \multirow{2}{*}{$\begin{array}{l}\text { Vitrified } \\
\text { Species }\end{array}$} & \multirow[b]{2}{*}{ MW } & \multicolumn{3}{|c|}{$\begin{array}{c}\text { Equivalent Oxides in } \\
\text { Simulant }\end{array}$} & \multirow{2}{*}{$\begin{array}{c}\text { Glassform } \\
\text { Number } 4 \\
\text { wt.pct. }\end{array}$} & \multirow{2}{*}{\multicolumn{2}{|c|}{$\begin{array}{rr}\text { Glass: } 25 & \text { Estimated } \\
\text { Loading } & \text { Solubility } \\
\text { wt.pct } & \text { wt.pct }\end{array}$}} \\
\hline & & gmoll & $\mathrm{gm} /$ & wt.pct. & & & \\
\hline 5102 & 60.08 & - & - & -1 & $57.20 \%$ & $42.90 \%$ & -1 \\
\hline Al2O3 & 101.96 & 0.51 & 52.00 & $12.75 \%$ & $19.44 \%$ & $17.77 \%$ & - \\
\hline $\mathrm{Na2O}$ & 61.98 & 4.77 & 295.55 & $72.49 \%$ & - & $18.12 \%$ & -1 \\
\hline 8203 & 69.62 & - & - & -1 & $12.60 \%$ & $9.45 \%$ & - \\
\hline $\mathrm{CaO}$ & 56.08 & 0.00110 & 0.06 & $0.02 \%$ & $6.20 \%$ & $4.65 \%$ & - \\
\hline $\mathrm{ZrO} 2$ & 123.22 & - & - & -1 & $2.80 \%$ & $2.10 \%$ & - \\
\hline $\mathrm{K} 2 \mathrm{O}$ & 94.20 & 0.25 & 23.55 & $5.78 \%$ & - & $1.44 \%$ & -1 \\
\hline Oما & 29.88 & - & - & - & $1.10 \%$ & $0.83 \%$ & - \\
\hline $\mathrm{Fe} 2 \mathrm{O} 3$ & 159.69 & 0.00039 & 0.06 & $0.02 \%$ & $0.65 \%$ & $0.50 \%$ & - \\
\hline $\mathrm{SO} 3$ & 80.06 & 0.043 & 3.44 & $0.84 \%$ & - & $0.21 \%$ & $0.50 \% /$ \\
\hline P2O5 & 141.94 & 0.022 & 3.05 & $0.75 \%$ & - & $0.19 \%$ & $3.50 \%$ \\
\hline Cs2O & 281.81 & 0.009 & 2.40 & $0.59 \%$ & - & $0.15 \%$ & -1 \\
\hline $\mathrm{MOO3}$ & 143.94 & 0.017 & 2.45 & $0.60 \%$ & $\cdots$ & $0.15 \%$ & - \\
\hline Sro & 103.62 & 0.017 & 1.76 & $0.43 \%$ & - & $0.11 \%$ & -- \\
\hline $\mathrm{Cr} 2 \mathrm{O} 3$ & 151.99 & 0.0044 & 0.66 & $0.16 \%$ & - & $0.04 \%$ & $0.40 \%$ \\
\hline $\mathrm{MgO}$ & 40.31 & 0.00100 & 0.04 & $0.01 \%$ & - & $0.002 \%$ & -1 \\
\hline $\mathrm{MnO} 2$ & 86.94 & 0.00042 & 0.04 & $0.01 \%$ & $\cdots$ & $0.002 \%$ & - \\
\hline $\mathrm{NaF}$ & 41.99 & 0.25 & 10.50 & $2.57 \%$ & - & $0.64 \%$ & $1.20 \%$ \\
\hline $\mathrm{NaCl}$ & 58.44 & 0.16 & 9.58 & $2.35 \%$ & - & $0.59 \%$ & $1.20 \%$ \\
\hline $\mathrm{Nal}$ & 149.89 & 0.017 & 2.55 & $0.63 \%$ & - & $0.16 \%$ & - \\
\hline Total & 66.94 & 6.09 & 407.69 & calcine & d wasteliter s & simulant & \\
\hline & & & 1630.75 & glass/it & ter simulant & & \\
\hline
\end{tabular}


3 Day PCT Data for Hanford High Sodlum

Low Level Surrogato Waste Glasses

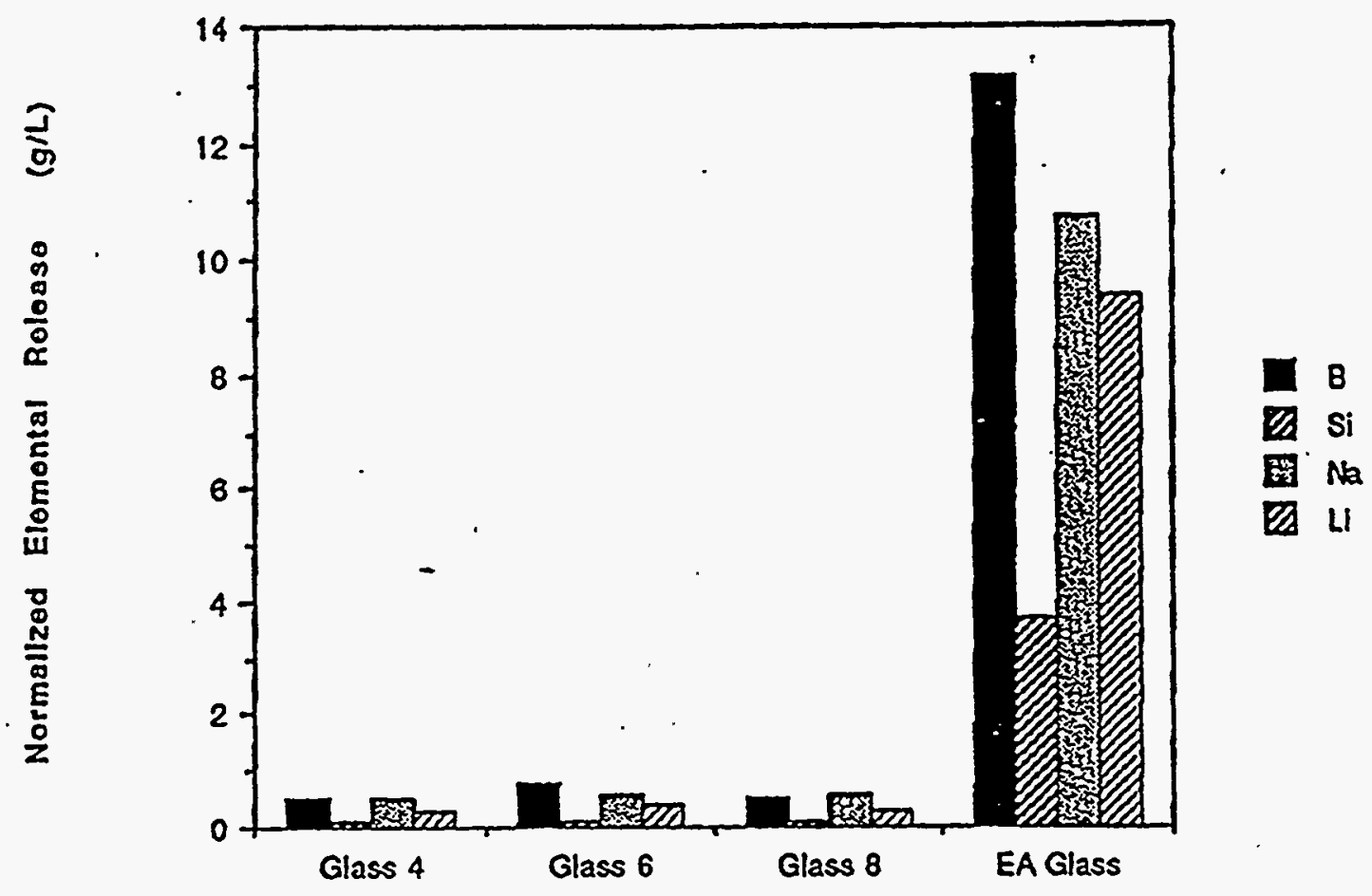

Figure 2.8 - Durability of SRTC Glass Formulations Compared to EA Glass 
Based on this data and assuming an empty crucible to start, the average glass residence time is calculated using the equation:

$$
T_{\text {res }}=\frac{v t}{W_{g} / G_{g}}
$$

A second method of determining residence time will also be implemented, in which a brief injection of some metal oxide not otherwise found in the glass product composition (such as $\mathrm{BaO}$ or $\mathrm{CeO}_{2}$ ) will be made into the feed blending screw hopper. The concentration of the tracer metal oxide in the glass product will then be recorded as a function of time, providing data on both the "plug flow" residence time between injection and first appearance in the product, and also the forward mixing behavior of the melter. 


\section{TEST MONITORING AND SAMPLING}

The Team will carry out a demonstration test of waste vitrification using the full simulant composition, of at least 24 hours simulant feed duration, in accordance with the approved test plan. The anticipated throughput of the demonstration test will be approximately 0.55 tonne/hr glass production, with an anticipated test duration of 30 hours simulant feed. It is assumed that WHC will observe the full test operations.

\subsection{GENERAL}

In order to properly document this test, the following data will be recorded and sampling conducted:

1. General chronology of events including operating behavior and any upsets or operating difficulties.

2. Simulant, glassformer, and product glass flowrates and cumulative injection.

3. Simulant makeup/storage and injection point temperatures.

4. Crucible melt zone and gas space temperatures.

5. Melter off-gas temperature, pressure, and flowrate.

6. Off-gas scrubber temperature, pressure, and flowrates.

7. On-line analysis of off-gas $\mathrm{NO}_{2}, \mathrm{CO}, \mathrm{CO}_{2}, \mathrm{H}_{2}$, and $\mathrm{O}_{2}$ concentrations.

8. Shaft furnace refractory temperature profile.

9. Plasma torch operating characteristics.

10. Cooling system temperatures and flowrates.

11. Periodic samples of simulant feed (approximately every 4 hours after reaching steady-state operation).

12. Periodic samples of product glass (at least every 4 hours after reaching steady-state operation), as well as timed collection of measured weights to determine production rates.

13. Periodic samples of off-gas scrubber liquor (at least every 4 hours after reaching steadystate operation). 
WHC-SD-WM-VI-011

Revision 0

14. Periodic samples of off-gas (approximately every 4 hours after reaching steady-state operation).

15. Aerosol/entrained particle samples of off-gas upstream and downstream of primary venturi scrubber.

16. Post-test sampling of separated melt phases observed in crucible.

Diagrams of data and sample collection points are shown in Figures 2.2, 2.4 and 2.7. Table 3.1 indicates the sample and data collection schedule, with sample locations identified with reference to Figures 2.2 through 2.7. Pre-test and post-test inspections which will be performed are listed in Table 3.2.

The application of the Westinghouse Plasma Torch for heating air has a considerable history. Therefore, the expected lifetime, maintenance time and replacement parts costs for the torch maintenance items (i.e., torch electrodes) will be based on the extensive historical data base built up from commercial applications such as the General Motors foundry at Defiance, Ohio. This data need not be obtained from this test.

Refractory wear data will be determined from the demonstration test. This will be accomplished by determining the thickness of the crucible (the most aggressively attacked refractory lined component) at various locations during the post-test inspection. Other refractory wear items are the pour spout and tap hole. To perform this inspection, the crucible will be removed from the melter shaft and all residues removed. The inside radius of the refractory will then be determined at the same points as those measured during the pretest inspection. The residual thickness of refractory in the pour spout will be measured directly as will the diameter of the tap hole.

\subsection{TEST MONITORING}

The Plasma Melter is equipped with on-line gas analyzers for obtaining off-gas concentrations of carbon oxides $\left(\mathrm{CO}, \mathrm{CO}_{2}\right)$, nitrogen oxides (NO/NO$)$, oxygen $\left(\mathrm{O}_{2}\right)$, and hydrogen $\left(\mathrm{H}_{2}\right)$. The NO/NO analyzer is a multirange Beckman, Model $951 \mathrm{H}$, with a 
Table 3.1 - Sample and Data Collection Schedule

\section{Type of Measurement}

\section{Temperatures/Thermocouples}

Cupola shaft walls

Crucible wall

Glass melt immersion thermocouple

Glass discharge zone

Melter offgas (horizontal duct)

Scrubber cooling water inlet

Scrubber cooling water outlet

Demister outlet

Scrubber/quench water supply

Shaft skin cooling water inlet

Shaft skin cooling water outlet

Scrubber HX cooling water inlet

Scrubber HX cooling water outlet

Feed tank

Torch air inlet

Torch methane inlet

Shroud air inlet

High-pressure coil water inlet

Field coil water outlet

Electrode water outlet

Tuyere copper coil water outlet

Steel tuyere water inlet

Steel tuyere water outlet

Pressures

Cupola shaft

Scrubber/demister inlet

Scrubber/demister outlet

Demister inlet

Blower inlet

Blower outlet

Scrubber/quench water supply

Feed recirculation line

Torch air inlet

Torch methane inlet

Shroud air inlet

High-pressure torch water inlet

Field coil water outlet

Electrode water outlet

Steel tuyere water inlet

Steel tuyere water outlet

Tuyere copper coil water outlet

\section{Location Frequency}

Method

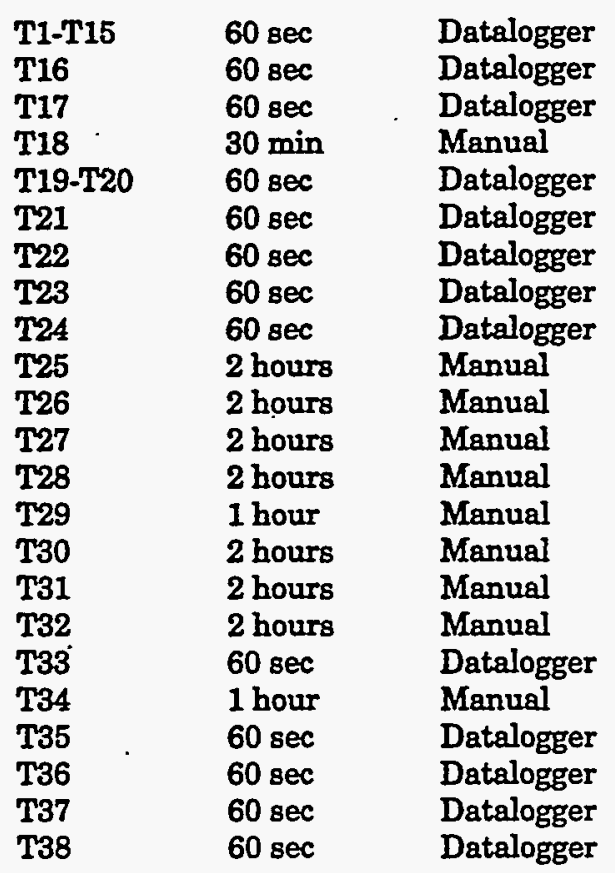

$\begin{array}{lll}\text { P1-P7 } & 60 \mathrm{sec} & \text { Datalogger } \\ \text { P8 } & 60 \mathrm{sec} & \text { Datalogger } \\ \text { P9 } & 60 \mathrm{sec} & \text { Datalogger } \\ \text { P10 } & 60 \mathrm{sec} & \text { Datalogger } \\ \text { P11 } & 60 \mathrm{sec} & \text { Datalogger } \\ \text { P12 } & 60 \mathrm{sec} & \text { Datalogger } \\ \text { P13 } & 60 \mathrm{sec} & \text { Datalogger } \\ \text { P14 } & 1 \text { hour } & \text { Manual } \\ \text { P15 } & 60 \mathrm{sec} & \text { Datalogger } \\ \text { P16 } & 2 \text { hours } & \text { Manual } \\ \text { P17 } & 60 \text { sec } & \text { Datalogger } \\ \text { P18 } & 2 \text { hours } & \text { Manual } \\ \text { P19 } & 2 \text { hours } & \text { Manual } \\ \text { P20 } & 2 \text { hours } & \text { Manual } \\ \text { P21 } & 2 \text { hours } & \text { Manual } \\ \text { P22 } & 2 \text { hours } & \text { Manual } \\ \text { P23 } & 2 \text { hours } & \text { Manual }\end{array}$

Elow Rates

Simulant feed

Prequench spray water

Venturi eductor water

Venturi spray water

Demister spray water

Scrubber HX cooling water

Primary afterburner nat. gas

Primary afterburner air
F1

F2

F3

F4

F5

F6

F7

F8

$\begin{array}{ll}15 \text { min } & \text { Manual } \\ \text { Variable } & \text { Manual } \\ 2 \text { hours } & \text { Manual } \\ 2 \text { hours } & \text { Manual } \\ 2 \text { hours } & \text { Manual } \\ 2 \text { hours } & \text { Manual } \\ 1 \text { hour } & \text { Manual } \\ 1 \text { hour } & \text { Manual }\end{array}$


WHC-SD-WM-VI-011

Revision 0

Type of Measurement

Secondary afterburner nat. gas

Secondary afterburner air

Torch air

Torch methane

Shroud air

Torch field-coil cooling water

Torch electrode cooling water

Steel tuyere cooling water

Tuyere copper coil cooling water

Melter shaft spray ring water

Pneumatic air purge

Prequench spray makeup water

Glass former feed (chunk)

Glass former auger rpm (frit)

Offges flowrate in shaft

Offgas flowrate in horizontal duct

Coke feed rate

Glass production rate

\section{Location Frequency Method}

$\begin{array}{lll}\text { F9 } & 1 \text { hour } & \text { Manual } \\ \text { F10 } & 1 \text { hour } & \text { Manual } \\ \text { F11 } & 60 \text { sec } & \text { Datalogger } \\ \text { F12 } & 1 \text { hour } & \text { Manual } \\ \text { F13 } & 60 \mathrm{sec} & \text { Datalogger } \\ \text { F14 } & 60 \mathrm{sec} & \text { Datalogger } \\ \text { F15 } & 60 \mathrm{sec} & \text { Datalogger } \\ \text { F16 } & 60 \mathrm{sec} & \text { Datalogger } \\ \text { F17 } & 60 \mathrm{sec} & \text { Datalogger } \\ \text { F18 } & \text { 2 hours } & \text { Manual } \\ \text { F19 } & 2 \text { hours } & \text { Manual } \\ \text { F20 } & 2 \text { hours } & \text { Manual } \\ \text { - } & \text { Per drum } & \text { Drum weight } \\ \text { R1 } & \text { 30 min } & \text { Manual } \\ \text { G1 } & 1 \text { hour } & \text { (see Sec. 2.3) } \\ \text { G2 } & 1 \text { hour } & \text { (see Sec. 2.3) } \\ \text { - } & \text { Per drum } & \text { Drum wt. } \\ \text { S7 } & 1 \text { hour } & \text { Timed samples }\end{array}$

Shaft Gas Composition

On-line monitors

Bomb samples

Aerosols/entrained solids

Solid-Liquid Compositions (samples)

LLW simulant

Glass product

Separated phases

Scrubber liquor

Scrubber sediment

Crucible/shaft

Glassformer-simulant slurry

Glass formers and coke

\section{Energy Input}

Plasma torch

Feed tank heater

Agitation horsepower

Recirculation pump horsepower

Feed pump(s) horsepower
S4-S6 4 hours

S7

S7

S8, 99

S10

S11

$\mathrm{S} 12$

S13

$\begin{array}{lll}\text { V1,I1,W1 } & 60 \mathrm{sec} & \text { Datalogger } \\ - & \text { Average } & \mathrm{V} \times \mathrm{I} \\ - & \text { Average } & \mathrm{V} \times \mathrm{I} \\ - & \text { Average } & \mathrm{V} \times \mathrm{I} \\ - & \text { Average } & \mathrm{V} \times \mathrm{I}\end{array}$

$60 \mathrm{sec}$

4 hours

10 hours

Datalogger

Laboratory

EPA SW-846

2 hours

End of run

4 hours

End of run

End of run

4 hours

Grab samples

Grab samples

Grab samples

Grab samples

Grab samples

Grab samples

Per lot
Grab samples 
Table 3.2 - Pre and Post Demonstration Test Inspections

\begin{tabular}{|c|c|}
\hline \multirow{3}{*}{$\frac{\text { Inspection Point }}{\text { Tuyere }}$} & Type of Inspection \\
\hline & Visual \\
\hline & Diameter measurements at 4 points \\
\hline Crucible & Visusal \\
\hline & Radius measurements at 8 points \\
\hline Pour Spout & $\begin{array}{l}\text { Visual } \\
\text { Thickness measurements at } 2 \text { points }\end{array}$ \\
\hline Tap Hole & Diameter \\
\hline
\end{tabular}

sensitivity of $1 \mathrm{ppm}$ and a maximum range of $10,000 \mathrm{ppm}$. The $\mathrm{O}_{2}$ analyzer is a multirange Beckman instrument with a sensitivity of $0.5 \%$ by volume and a maximum of range of $25 \%$ by volume. The $\mathrm{H}_{2}$ analyzer is a Thermatron instrument with a sensitivity of $0.1 \%$ by volume and a maximum range of $10 \%$ by volume. The outputs from the analytical instruments are constantly monitored and recorded by the control room data acquisition system.

In addition to the on-line analytical capabilities, the Plasma Center has developed and will utilize qualified vendors for analyzing feed, product and offgas samples. For the current program, however, a WHC designated laboratory will analyze simulant feed, Plasma Melter vitrified product, and scrubber water for chemical species composition. Air Quality Services, Inc. of Pittsburgh, Pennsylvania, will analyze Plasma Melter and exhaust stack off-gases for chemical species and to verify compliance with air quality standards. Affiliated Environmental Services, Inc., will supply the EPA SW-846 analysis sampling of melter exit gases for entrained aerosols and particulates and provide both particle size and chemical analysis of the collected materials.

Process control instrumentation includes strategically located thermocouples, pressure transducers, flowmeters, RTD's, power meters, and voltmeters to control, monitor, and record torch power, feed streams, product stream, and off-gas. Critical data are recorded on the computer data acquisition systems and chart recorders allowing real-time control of process parameters such as torch input power, feed flow, process gas flow, glassformer input rate, product formation rate, product stream temperature, and off gas temperature, flow rate and composition. Data collection and 
process control are further enhanced by operator maintained data reduction graphs and charts. A Hewlett Packard Model 3054A Automatic Data Acquisition/Control System interfaces with several personal computers (PC's) for data archiving and data reduction.

Process control equipment includes a programmable logic controller (PLC) for monitoring critical process variables and alarming or activating system shut-down when alarm set points have been exceeded. The low-level waste simulant slurry flowrate, glassformer flowrate, torch input power, and process gas flowrate are operator controlled to obtain the desired product production rate, desired product composition and Plasma Melter operating conditions.

\subsection{SAMPLING}

The sampling procedure to be used for this program will follow that recommended by DOE and titled Vitreous State Laboratory Sampling Instructions. Where possible, each sample taken will be mixed and split to produce the quadruplicate samples required by the QAP (primary lab, backup lab, archive, WSTC). The samples for which this applies are:

1. Feed samples (simulant, glassformers, and blended feed)

2. Glass product, separated melt phase, and melter solid residues

3. Offgas scrubber (liquor, sediment)

4. Refractory in contact with glass (before and after)

The remaining samples (product glass and aerosols/entrained particulates) will be taken sequentially with a minimum elapsed time between the drawing of each sample in the particular sequence. All sample containers will be prelabeled and the following information entered:

1. Sample Number (described below)

2. Sample Date (date sample taken)

3. Time Sampled (time sample taken)

4. Sampler Initials (initials of sample collector at time of sampling)

5. Laboratory (destination for the sample) 


\subsubsection{Sample Numbering System}

The sample numbering system consists of seven separate identifiers which will use the following coding scheme (see Figure 3.1):

1st Character: Vendor Identifier - Consists of the first letter in the vendors name i.e "W".

2nd Character: Test Phase Identifier - i.e. " 1 " for Phase I testing.

3rd Character: Sample Type Identifier ("T" and "W" not expected to be used). "S" = LLW Simulant

" $\mathbf{A}$ " = Additives/Glassformers

"F" = Feed, Mixed

"T" = Intermediate (e.g., samples between feed and glass product)

" $G "$ = Glass Product

"O" = Offgas

"W" $=$ Waste

"C ${ }^{n}=$ Coke

"R" = Refractory

" $L$ " = Scrubber Liquor

$" \mathrm{E}^{n}=$ Entrained Solids/Aerosols

“ $\mathrm{X}$ " = Scrubber Sediment

" $N$ " = Separated Product Salt Phases

" $\mathrm{Z}$ " = Melter Solid Residues

4th Character: Sample point number. Used to designate multiple sample points for a specific sample type.

5th through 7th Characters: Serial sample number. Corresponds to the time samples are taken (e.g., assuming a four hour sampling schedule, 10:00 on the first day of testing, all samples taken have a -101 extension, 14:00 on the first day of testing, all samples taken have a -102 extension, 10:00 on the second day of testing, all samples 


\begin{tabular}{|c|c|c|c|c|c|c|c|c|c|}
\hline W & 1 & $\mathbf{H}$ & 1 & - & 0 & 0 & 1 & 0 & 1 \\
\hline $\begin{array}{c}\text { Vendor } \\
\text { Identification }\end{array}$ & $\begin{array}{c}\text { Phase } \\
\text { Identifier }\end{array}$ & Sample Type & $\begin{array}{c}\text { Sample Point } \\
\text { Number }\end{array}$ & Hyphen & Serial & Sample & Number & Lab ID & Snapshot Set ID \\
\hline WSTC & Phase l & Feed Sample & Sample Point I & & Sample & Number & $I$ & Quanterra & I= 1" Mass Balance Sel \\
\hline
\end{tabular}

\begin{tabular}{|c|c|}
\hline Vendor & Sample Type \\
\hline \multirow[t]{9}{*}{$\bar{W}=\mathrm{WSTC}$} & $\mathrm{S}=$ Simulant \\
\hline & $\Lambda=\Lambda$ dditives \\
\hline & $F=$ Feed, Mixed \\
\hline & $1=$ Intermediate \\
\hline & $G=$ Glass \\
\hline & $\mathrm{O}=\mathrm{O}$ Orf-gas \\
\hline & $W=$ Waste \\
\hline & ? = Open \\
\hline & $7=$ Open \\
\hline
\end{tabular}

\section{Lab in Sample Set ID C-Coming 1- 1" Mass Balance Set} $0-$ Archive (GEL) $2=2^{n}$ Mass Balance Set P - PNL

Q- Quanterra Blank = Individual Pts.

$U=$ USOS

$W=222-S$

Figure 3.1 - Melter Project: Sample Numbering Scheme - WSTC 
have a -107 extension, etc). Since the WSTC test program will consist of three Trial Heats and one long-term demonstration test, the first serial number character will designate which of the four tests is referred to (e.g. the first Trial Heat \#1 samples will be designated with a -101 extension, the first sample of the fourth Demo test with a 401 extension, etc.).

8th Character: Laboratory identifier. Used to designate sample destination:

$$
\begin{aligned}
& \mathbf{Q}=\text { Quanterra } \\
& \mathbf{P}=\text { Pacific Northwest Laboratory } \\
& \mathbf{W}=\text { Westinghouse Hanford Co. - 222-S Laboratory } \\
& \mathbf{G}=\text { Geotechnical Engineering Laboratory - W Hanford Company } \\
& \mathbf{C}=\text { Corning } \\
& \mathbf{U}=\text { USGS } \\
& \mathbf{M}=\text { W Waltz Mill Site Analytical Laboratory } \\
& \mathbf{T}=\text { Savannah River Technology Center } \\
& \mathbf{S}=\text { W Science and Technology Center }
\end{aligned}
$$

9th Character: Snapshot set identifier. This is used to designate samplings where samples are taken from all applicable sample and data points (this is to facilitate easy data identification for mass balance, this will usually correlate with offgas measurements)

Figure 3.1 depicts the abov described sample numbering system to be used for the Melter Project.

\subsubsection{Sample Labeling}

Sample labels will be supplied by WHC or will be generated by WSTC. There are five fields of information required for sample labeling:

1. Sample Number (described above)

2. Sample Date (date sample taken)

3. Time Sampled (time sample taken)

4. Sampler Initials (initials of sample collector at time of sampling) 
5. Laboratory (destination for the sample)

- Quanterra

- Pacific Northwest Laboratory

- Westinghouse Hanford Co. - 222-S Laboratory

- Geotechnical Engineering Laboratory - W Hanford Company

- Corning

- USGS

- W Waltz Mill Site Analytical Laboratory

- Savannah River Technology Center

- W Science and Technology Center

\subsubsection{Chain of Custody}

Chain of Custody (COC) for samples is initiated by the sample collector at the time of sampling. Examples of COC forms are shown in Appendix A. At the end of the shift, the COC should be placed in the same locked storage area as the samples. Boxes on the Chain of Custody form not mentioned in this section will be completed by WHC representatives. There are ten areas of concern for samplers.

- Collector: Name of person collecting sample. This person initiates the COC form

- Sample Type: The type of sample collected (e.g., simulant, additive, feed, etc.)

- Possible Hazards: Any potential hazards associated with the samples

- Sample Number: The number generated for the sample (Section 3.3.1)

- Sample Point: Point in the process where the sample was taken

- Date Sampled: Date sample was taken

- Time: Time sample was taken

- Relinquished By: Sample is signed over by the collector to another custodian as needed. e.g., this will also apply to the custodian, shipper, and transporter). 
Received By: Person receiving custody of the sample (e.g., custodian, shipper, transporter, laboratory)

Note: Custody must be relinquished and received each time the sample changes hands (e.g., from the collector to the shipper, sample must be relinquished just prior to shippment even though the transporter may not actually sign the form, and finally from the transporter to the lab custodian).

- Special Instructions/Remarks: Complete this section if there are any special instructions for the laboratory

\subsubsection{Sample and Shipping Log}

A sample and shipping log is required for summary sampling information and sample tracking and an example is shown in Figure 3.2. There are eight fields of information required for the sample log.

- Sample Number

- Sample Date

- Sample Time

- Sampler Initials

- Sample Type: Type of samples (sample types listed above in Section 3.3.1)

- Sample Point: Location in the process where the sample was taken

- Sample Destination: Location the sample will be shipped to for analysis/archive (Section 3.3.2)

- Shipment Date: Date samples sent for analysis/archiving

\subsubsection{Sequential Steps}

The following steps should be followed to ensure positive chain of custody and sample tracking:

1. Obtain sample

2. Generate sample number (Section 3.3.1)

3. Label sample (Section 3.3.2) 
WHC-SD-WM-VI-011

Revision 0

\begin{tabular}{|c|c|c|c|c|c|c|c|}
\hline $\begin{array}{l}\text { Sample } \\
\text { Number }\end{array}$ & $\begin{array}{c}\text { Sample } \\
\text { Date }\end{array}$ & $\begin{array}{c}\text { Time } \\
\text { Sampled }\end{array}$ & $\begin{array}{c}\text { Sampler } \\
\text { Initials }\end{array}$ & $\begin{array}{l}\text { Sample } \\
\text { Matrix }\end{array}$ & $\begin{array}{c}\text { Sample } \\
\text { Point }\end{array}$ & $\begin{array}{c}\text { Sample } \\
\text { Destination }\end{array}$ & $\begin{array}{l}\text { Shipment } \\
\text { Date }\end{array}$ \\
\hline VIS1-001Q1 & $10 / 5 / 94$ & $10: 00$ & $\overline{A B C}$ & Simulant & $\overline{X Y Z}$ & Quanterra & $10 / 7 / 94$ \\
\hline WIS1-001P1 & $10 / 5 / 94$ & $10: 00$ & $A B C$ & & $\mathrm{XYZ}$ & & $10 / 7 / 94$ \\
\hline IWI & $10 / 5 / 94$ & 10: & C & nt & $X Y Z$ & 222-S & $10 / 7 / 94$ \\
\hline G1 & $10 / 5 / 94$ & & & & $X Y Z$ & Archive & $10 / 7 / 94$ \\
\hline Q1 & $10 / 5 / 94$ & $10:$ & & & DEF & & $10 / 7 / 94$ \\
\hline $1 \mathbf{A}$ & $10 / 5 / 94$ & 10: & & & DEF & & $10 / 7 / 94$ \\
\hline VIAI & $10 / 5 / 94$ & $10: 00$ & & & DEF & & $10 / 7 / 94$ \\
\hline$B A$ & $10 / 5 / 94$ & 10: & & & DEF & & \\
\hline 21 & $10 / 5 / 94$ & 10: & $A B C$ & & JKC & Qua & $10 / 7 / 94$ \\
\hline $11 F$ & $10 / 5 / 94$ & 10: & & & गKX & & $10 / 7 / 94$ \\
\hline 11 & $10 / 5 / 94$ & 10 & & & JK & & $10 / 7 / 94$ \\
\hline $1 F$ & $10 / 5 / 94$ & 10: & & & JKL & & $10 / 7 / 94$ \\
\hline $1 G$ & $10 / 5 / 94$ & 10: & & & MNO & & $10 / 7 / 94$ \\
\hline $11 G$ & $10 / 5 / 94$ & 10: & $C$ & & MNO & & $10 / 7 / 94$ \\
\hline Gl & $10 / 5 / 94$ & $10:$ & C & & MNO & & $10 / 7 / 94$ \\
\hline VIF1 & $10 / 5 / 94$ & $14:$ & 3C & & $\overline{X Y Z}$ & & $10 / 7 / 94$ \\
\hline $1 \mathrm{~F} 1$ & $10 / 5 / 94$ & 14 & $A B C$ & & $\mathrm{XYZ}$ & & $10 / 7 / 94$ \\
\hline $1 F$ & $10 / 5 / 94$ & 14 & $A B C$ & & $\mathrm{XYZ}$ & 22 & $10 / 7 / 94$ \\
\hline G & $10 / 5 / 94$ & & $A B C$ & & $X Y Z$ & & $10 / 7 / 94$ \\
\hline $1 G$ & $10 / 5 / 94$ & & & & DEF & & $10 / 7 / 94$ \\
\hline $11 \mathrm{G}$ & $10 / 5 / 94$ & 14: & & & DEF & & $10 / 7 / 94$ \\
\hline$G$ & $10 / 5 / 94$ & 14: & & & DEF & ive & $10 / 7 / 94$ \\
\hline $1 G 1$ & $10 / 5 / 94$ & $14: 00$ & $1=$ & & GEII & Cor & $10 / 7 / 94$ \\
\hline 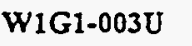 & & & & & $-\infty$ & & \\
\hline $1 \mathrm{Gl}-003 \mathrm{G}$ & $10 / 5 / 94$ & $14: 00$ & $B C$ & Glass & GHI & Archive & $10 / 7 / 94$ \\
\hline
\end{tabular}

Shipping destinations may include Quanterra, Battelle Pacific Northwest Laboratory, Westinghouse 222-S Laboratory, Coming, and USGS, as well as Westinghouse for archive samples.

Sample numbers ending in " 1 " indicate a full set of samples obtained from all sample points.

Sample numbers without an " $I$ " indicate samples obtained from selected sample points.

Figure 3.2 - Sample and Shipping Log - WSTC 
6. Complete sample log information (Section 3.3.4)

7. Store sample in a locked area with the Chain of Custody form until shipment.

\subsubsection{Samples to be Taken}

Samples and sample quantities which will be sent to appropriate laboratories (see Appendix A) include:

1. Liquid samples $(S, L)$ - 6 liters

2. Solid samples (A, G, R) - 400 grams

3. Slurry samples (F) -400 grams

4. Separated melt phase $(N, Z)$ - as available

5. Offgas scrubber sediment - (X) - 600 grams)

6. Aerosols/entrained particulates $(E)$ - as available

7. Refractory in contact with glass ( $R$; before and after) -400 grams each

8. Offgas bomb samples (O) -2 samples, $75 \mathrm{ml}$ each

\subsection{DETERMINING LIMITS ON SO $, \mathrm{Cl}_{2} \mathrm{PO}_{4}, \mathrm{~F}$ AND CrO,}

It is of interest in the production of vitrified product from a variety of waste compositions to characterize the solubility of limits of certain low-solubility species in the final waste glass product. These species include sulfate, chloride, fluoride, phosphate, and chromate, all of which may form second phase molten salt layers in the melter if their solubility is exceeded. Based on their experience with formulation of high-level waste glass of similar composition, Savannah River Technology Center has estimated the solubility of these five species in the Composition \#4. Table 3.3 presents these estimates compared to the anticipated concentrations in the simulant glass to be produced during WSTC test operations. It is seen that none of the five species exceed $50 \%$ of their expected solubility limit, 80 that no second phase formation is expected. Note that none was observed during SRTC crucible melt tests of the Composition \#4 glass formulation. 
Table 3.3 - Expected Concentration of Low-Solubility Salts in Glass

\begin{tabular}{lccc}
\multicolumn{1}{c}{ Species } & $\begin{array}{c}\text { Final Glass } \\
\text { Concentration (\%) }\end{array}$ & $\begin{array}{c}\text { Estimated } \\
\text { Solubility } \\
\text { Limit (\%) }\end{array}$ & $\begin{array}{c}\text { Fraction of } \\
\text { Solubility Limit } \\
\mathrm{NaCl}\end{array}$ \\
\cline { 2 - 3 } & 0.51 & 1.2 & 0.43 \\
$\mathrm{NaF}$ & 0.57 & 1.2 & 0.48 \\
$\mathrm{Na}_{2} \mathrm{SO}_{4}$ (as $\mathrm{SO}_{3}$ ) & 0.19 & 0.5 & 0.38 \\
$\mathrm{Na}_{3} \mathrm{PO}_{4}$ (as $\mathrm{P}_{2} \mathrm{O}_{5}$ ) & 0.17 & 3.5 & 0.05 \\
$\mathrm{Na}_{2} \mathrm{CrO}_{4}$ (as $\mathrm{Cr}_{2} \mathrm{O}_{3}$ ) & 0.04 & 0.4 & 0.10
\end{tabular}

\subsection{USE OF DATA FOR SCALING CALCULATIONS}

There are key parameters which are used to scale the Westinghouse Plasma Melter. These are:

1. the gas flow per unit area in the melter shaft,

2. the power input from the torch,

3. composition of the gas (solids, aerosols vaporized salts),

4. energy losses from the cupola through the wall and from the gas,

5. energy losses from the torch,

6. waste and glassformer flow rates, and

7. water content of the waste and glassformers.

These parameters will be determined as part of this test.

The gas flow per unit area will be measured in the upper part of the melter shaft for both the coke/glassformer and the glassformer frit feed approaches. For the measured gas rate, the amount of carryover (as solid, aerosol and vapor) will also be measured. Based on these numbers, the diameter of a full scale melter as well as the load on the gas cleaning system could be calculated. 
The power input from the torch minus the energy losses from the torch and melter result in the net power to the waste. If the energy required to vaporize the water content of the waste and glassformers is then subtracted, the net power to calcine and melt the waste and glassformers results. The net power to melt can then be used in optimization studies to size the plasma torches given the water content of the waste and glassformers and the size of the melter. 
WHC-SD-WM-VI-011

Revision 0

THIS PAGE IS INTENTIONALLY BLANK 


\section{TEST SCHEDULE}

The goal of Phase 1 will be to conduct proof of principle testing of the Plasma Melter system technology for the vitrification of high-sodium, low-level liquid waste for use at the Westinghouse Hanford Site. Phase 1 will provide the basis for an optional Phase 2 program to demonstrate the concept in a performance testing program. A Test Schedule is described in Sections 4.1. Section 4.2 presents the schedule for delivering the various reports describing the tests and test results.

\subsection{TEST SCHEDULE}

The Team will carry out a demonstration test of waste vitrification using the full simulant composition, of at least 24 hours simulant feed duration, in accordance with the approved test plan. The anticipated throughput of the demonstration test will be approximately 0.55 tonne/hr glass production, with an anticipated test duration of 30 hours simulant feed. The amount of $10 \mathrm{M}$ sodium waste simulant required for the demonstration test will therefore be about 3.6 tonnes of calcined solids. The expected test chronology is outlined in Table 4.1. 
WHC-SD-WM-VI-01I

Revision 0

Table 4.1 - Demonstration Test Chronology Anticipated Time Zero = 8:00 am, December 7, 1994

Event

Load frit feed auger hopper

Start Time

End Time

Load waste simulant

(Hours)

(Hours)

Pretest inspection

$-24$

$-20$

Begin waste simulant heatup to $30^{\circ} \mathrm{C}$

$-48$

$-40$

Begin melter beatup

$-48$

$-40$

Begin water injection

$-24$

Begin waste simulant and glassformer injection

$-16$

Begin hot cleanout

31

1

Begin cupola cooldown

33

Remove crucible for post-test inspection

72

\subsection{SCHEDULE FOR TEST REPORTS}

The delivery schedule for test reports is provided in Table 4.2. Note that the original WSTC proposal had requested that the Draft Full Test Report (DFTR) be due 30 days following receipt of analytical data, to allow time for computation of material balances. At the request of WHC, the original schedule stated in the RFP has been adhered to (delivery of the DFTR 45 days from completion of the demonstration test), with the recognition that this document may not contain material balance results due to delays in obtaining analytical data. However, both WHC and WSTC have agreed that a revision of the Full Test Report may be generated to incorporate material balance calculations performed after delivery of the DFTR. 
Table 4.2 - Technical Documentation Delivery Schedule PHASE 1: PROOF OF PRINCIPLE TESTING

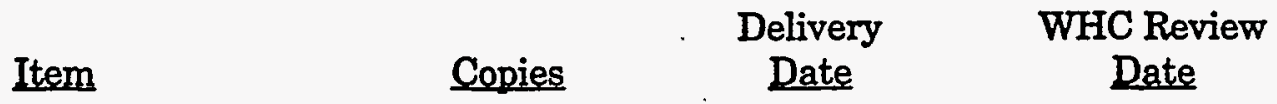

Preliminary (Quick Look) Test

Summary Report (PTSR)

5

$12 / 21 / 94$

Technical Information Report (TIR)

Draft (DTIR)

5

01/09/95

01/30/95

Final (FTIR)

5

02/13/95

Life Expectancy and Reliability) (LERR) 5

01/09/95

Detailed Full Test Reports (FTR)

Draft (DFTR)

5

02/01/95

$02 / 22 / 95$

Final (FFTR)

03/08/95

Testing Definition for Phase 2

2

02/15/95 
WHC-SD-WM-VI- 011 Revision 0

THIS PAGE IS INTENTIONALLY BIANK 


\section{ENVIRONMENTAL}

Based on previous testing, the quality of the gaseous emissions from this test will meet all the regulatory requirements imposed on the Plasma Center. Compliance with appropriate limits is determined by the Pennsylvania Department of Environmental Resources (PADER), to whom estimates of total $\mathrm{CO}, \mathrm{CO}_{2}, \mathrm{NO}_{z}$, and $\mathrm{SO}_{\mathbf{z}}$ emissions are submitted prior to testing, and approval obtained in advance of any test activities.

Secondary wastes to be disposed of will be the:

1. Unused feed heel (estimated $10 \%$ of inventory, or 1600 liters) which must be treated as a RCRA waste if it cannot be used in further testing or returned to Hanford.

2. Glass product (maximum $26,000 \mathrm{~kg}$ ) which can probably be disposed of as a non-hazardous waste.

3. Scrubber liquor (roughly 30,000 liters) which will require filtration for recovery of sediments. The sediments will be RCRA solids while the liquids will be disposed of through a commercial chemical waste disposal service.

4. Tank flush liquids (maximum of 4,000 liters) which will be mixed and treated with the scrubber liquids above. 
WEC-SD-WM-VI - 011

Revision 0

THIS PAGE IS INTENTIONAIIY BIANR 
WHC-SD-WM-VI-011

Revision 0

\section{APPENDIX A}

\section{CHAIN OF CUSTODY FORMS}

A-1 


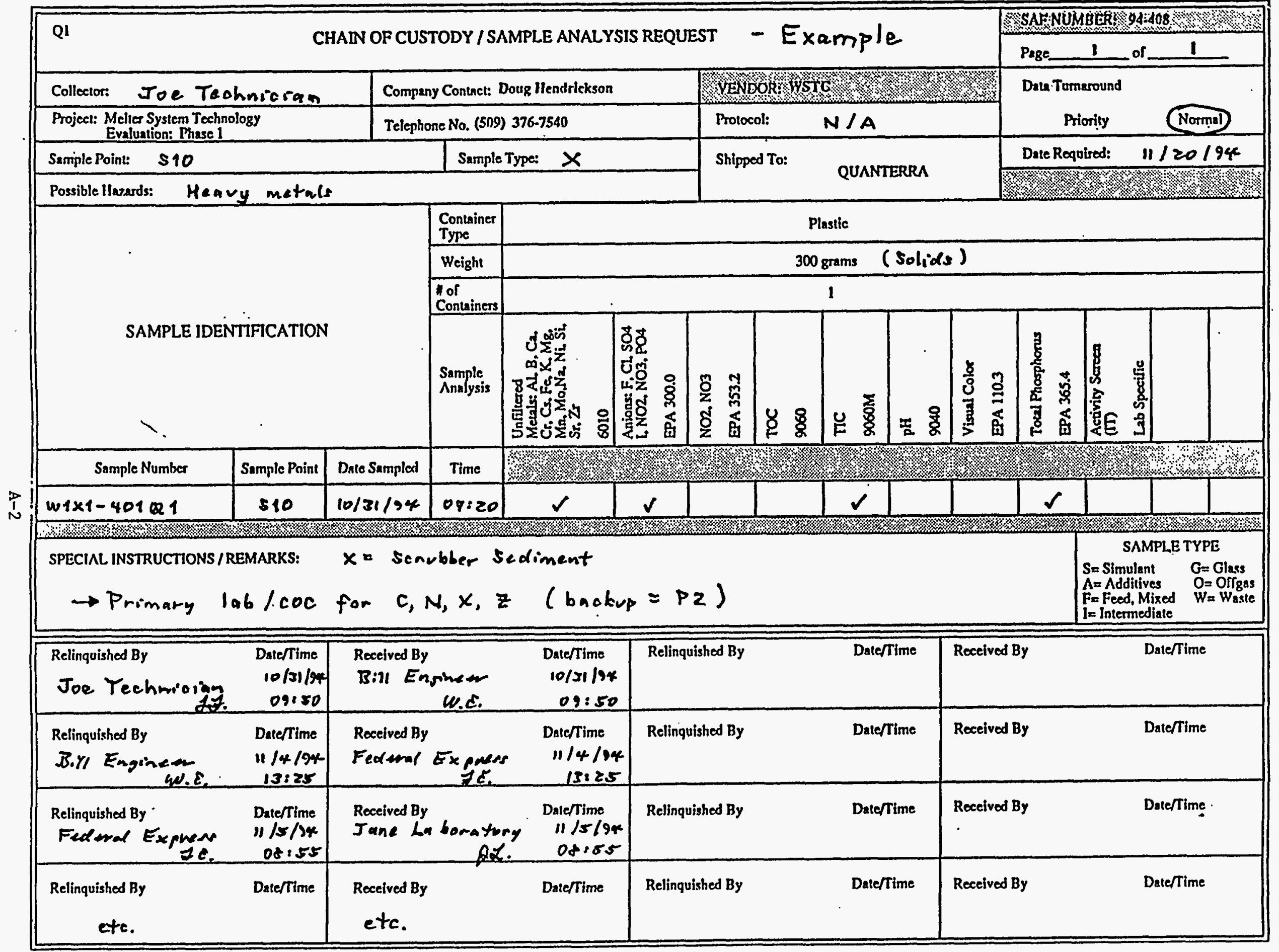




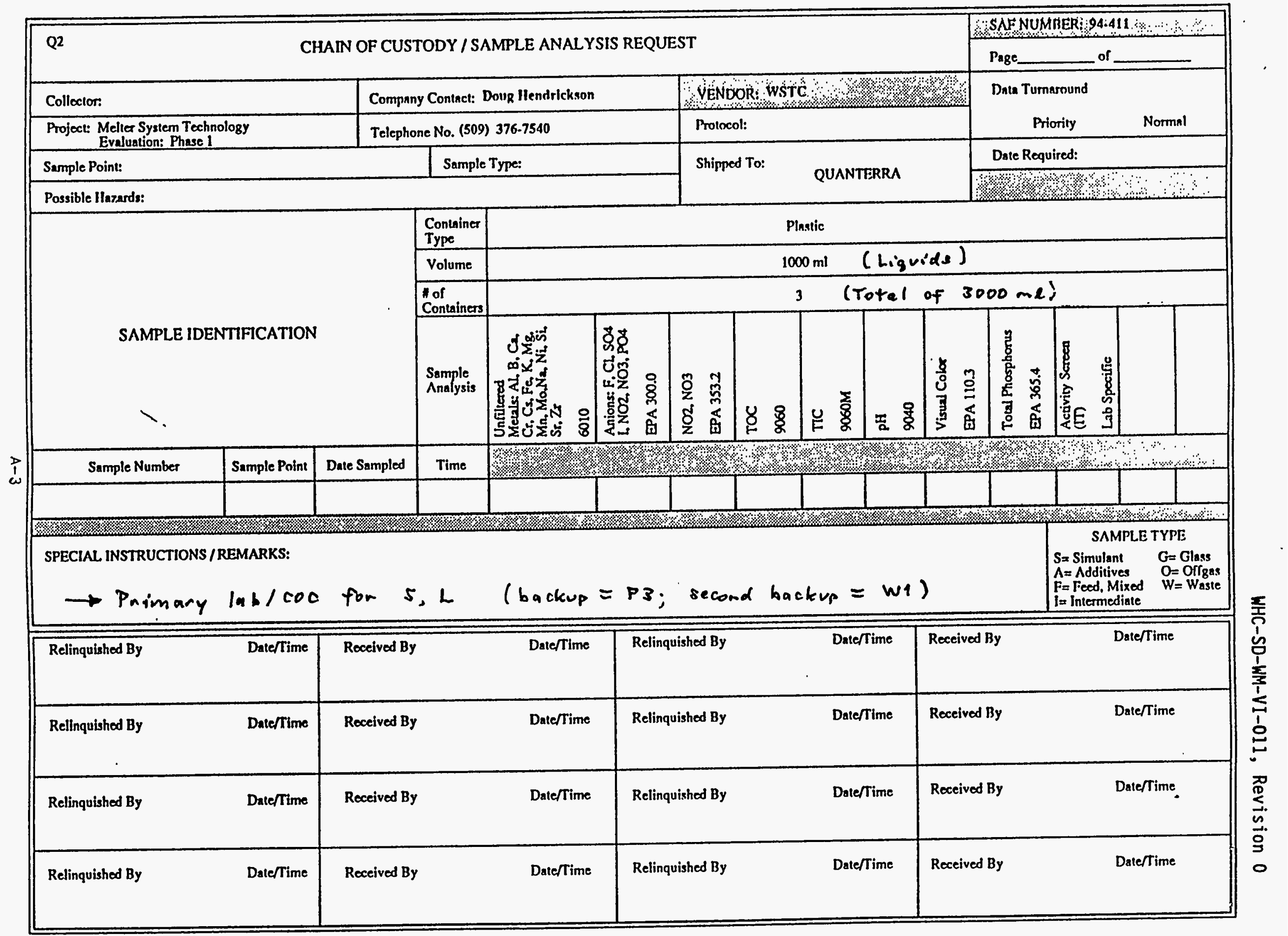














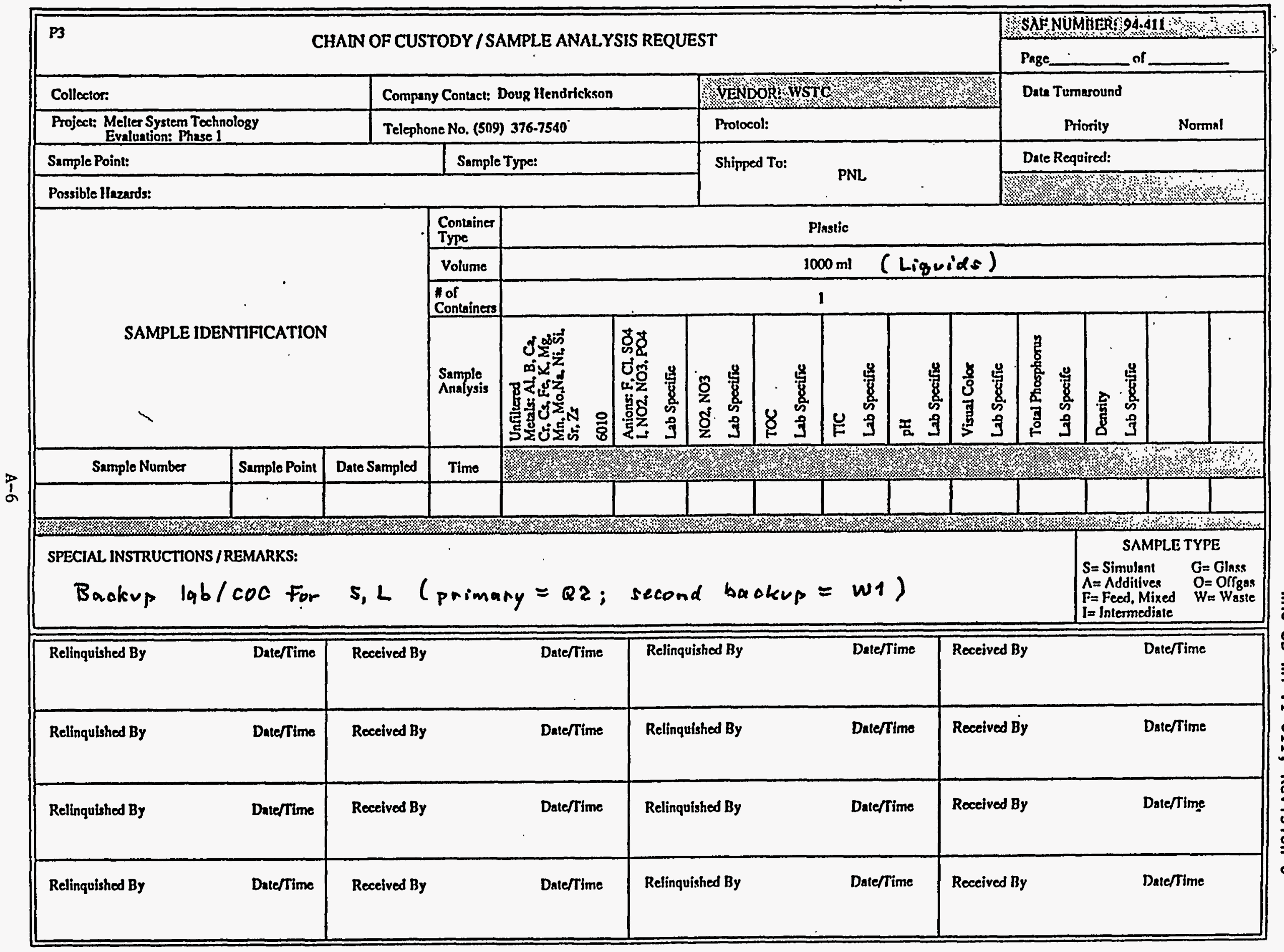




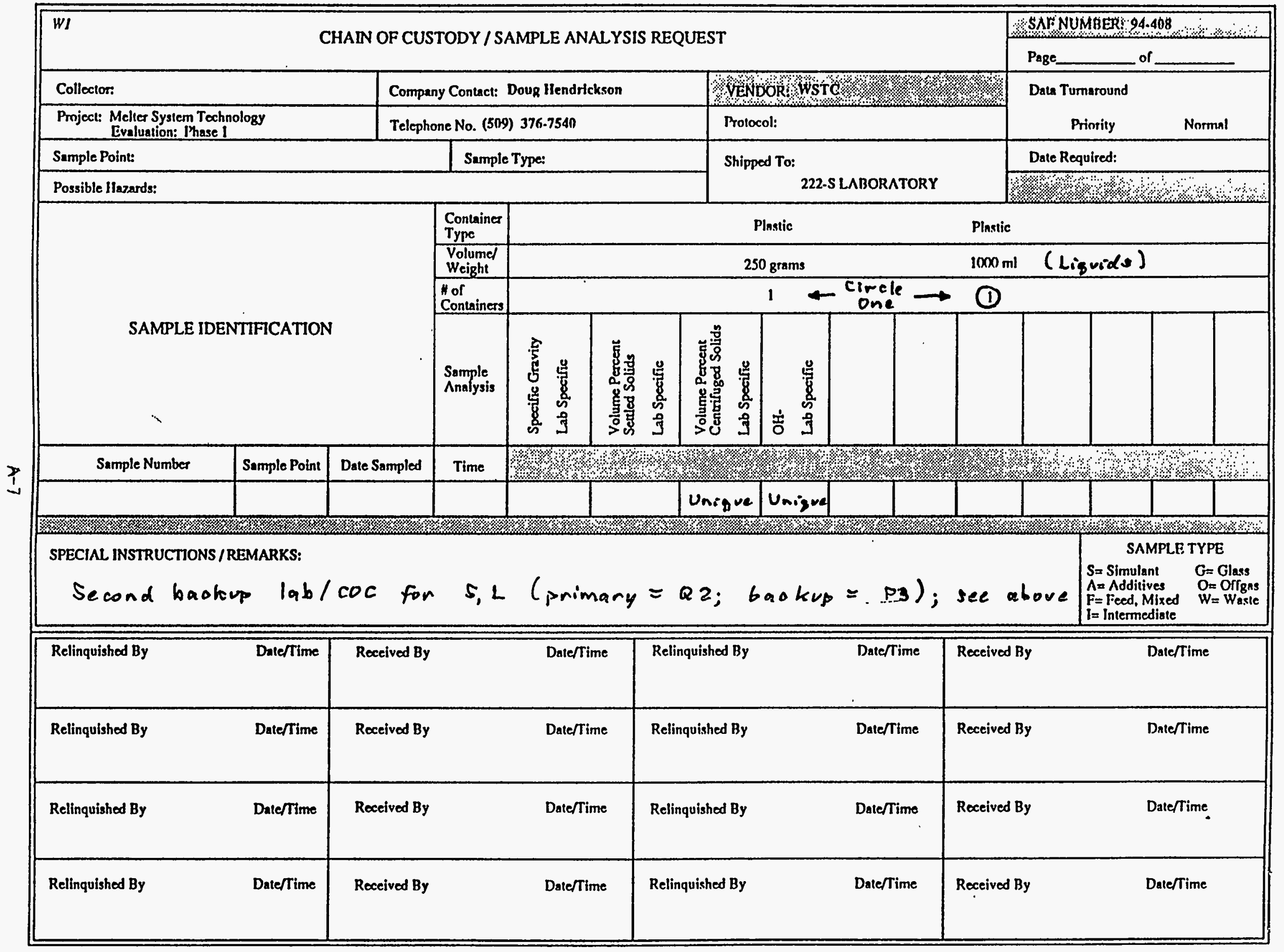




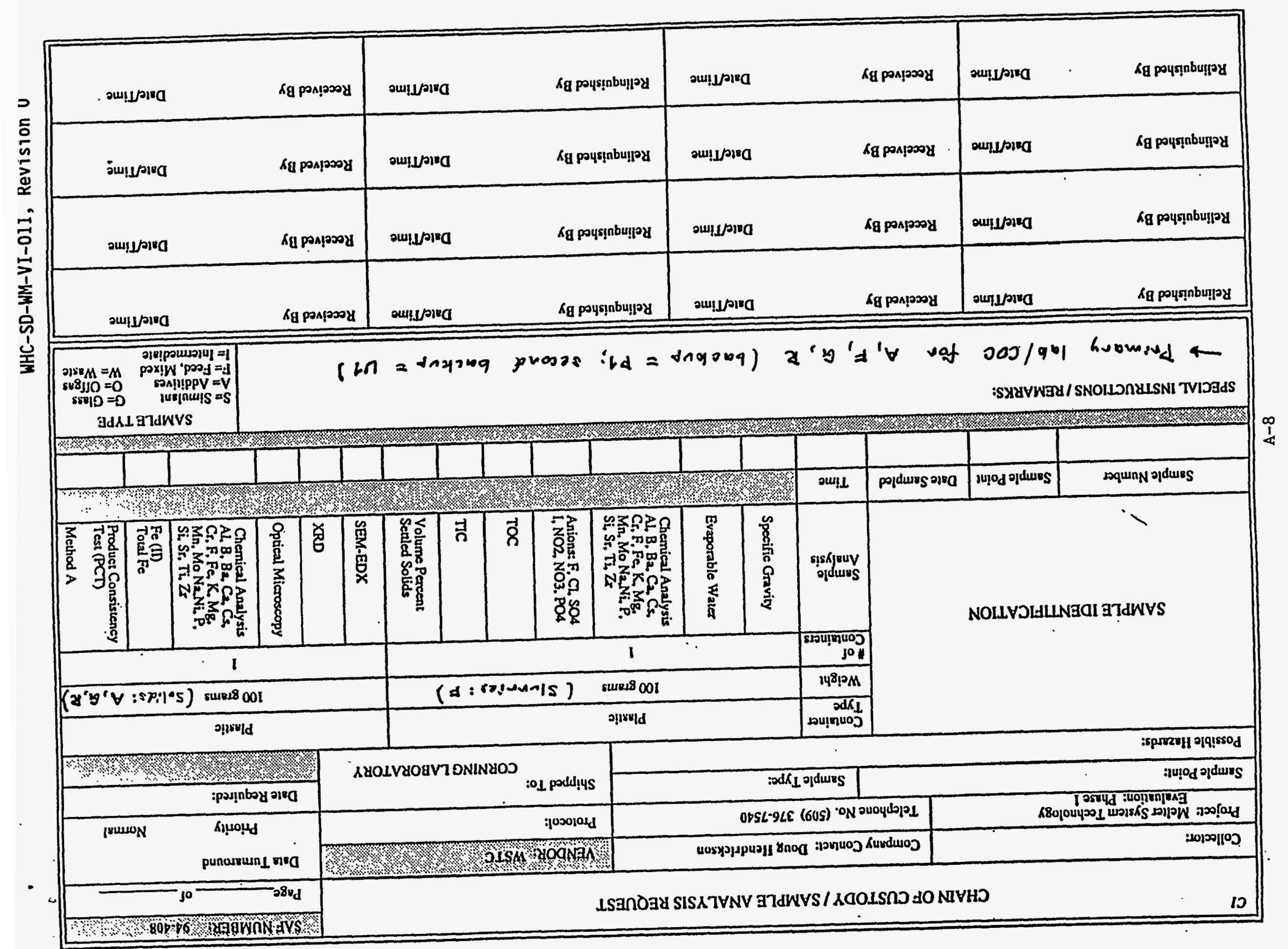




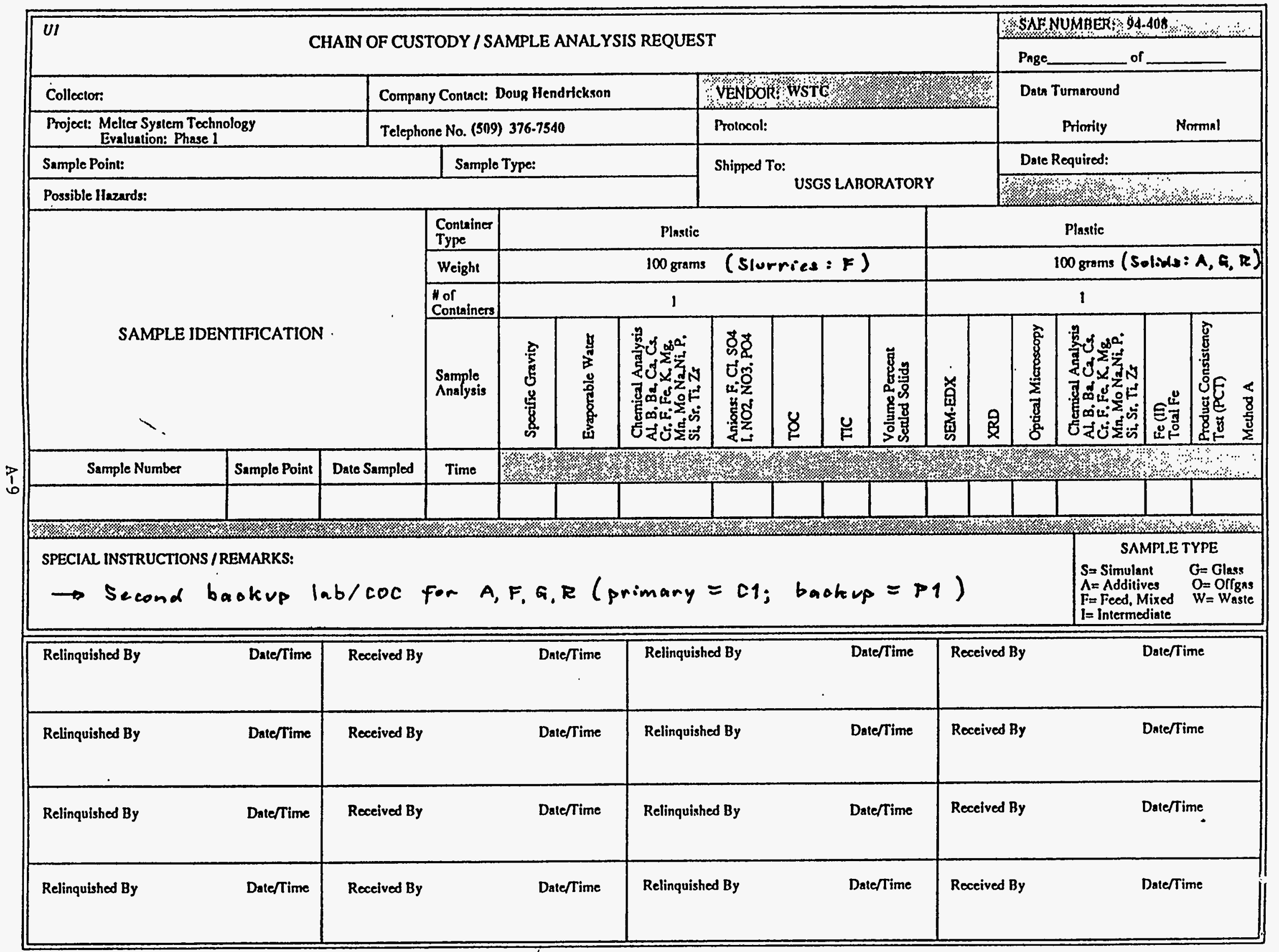




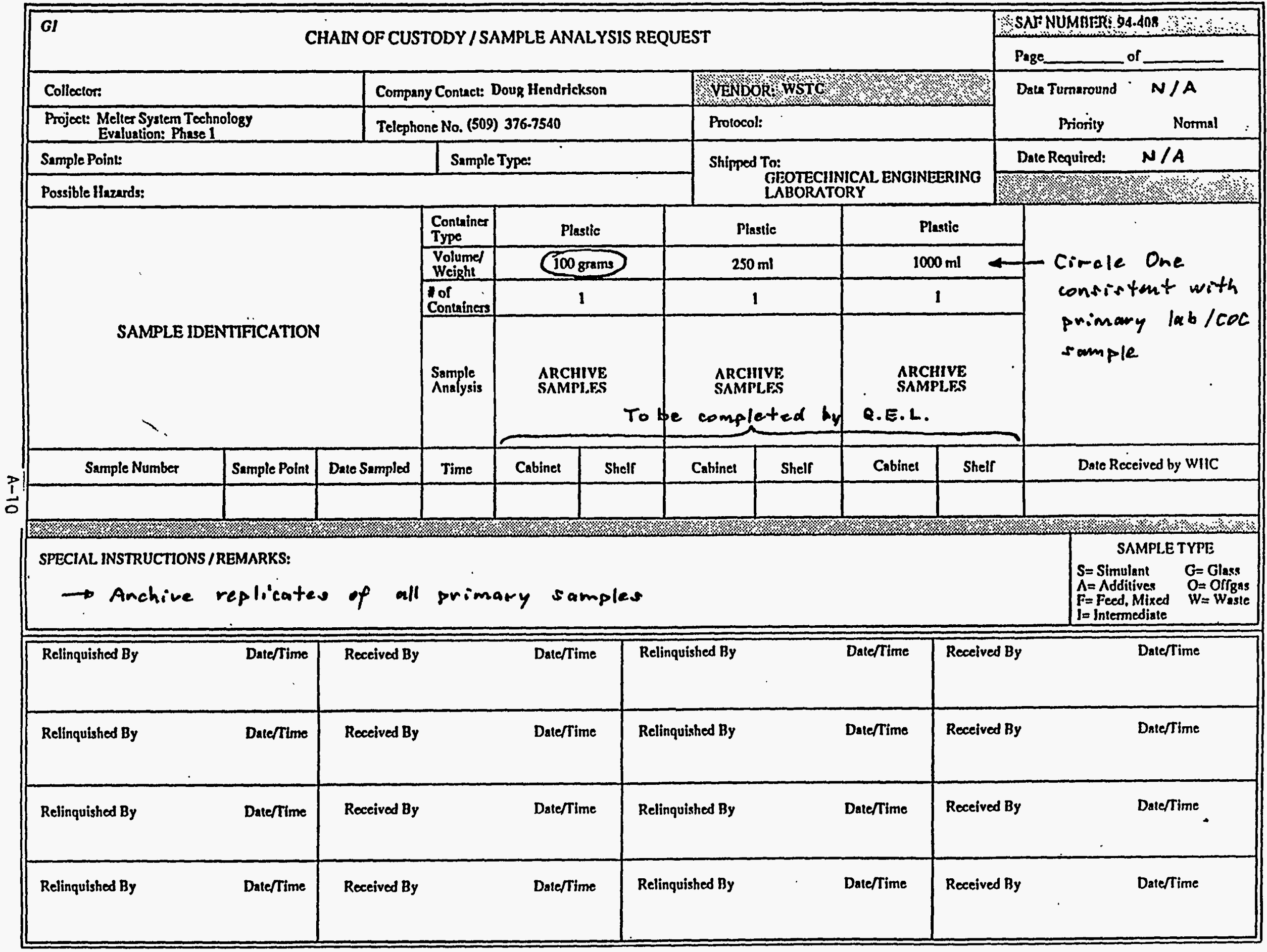




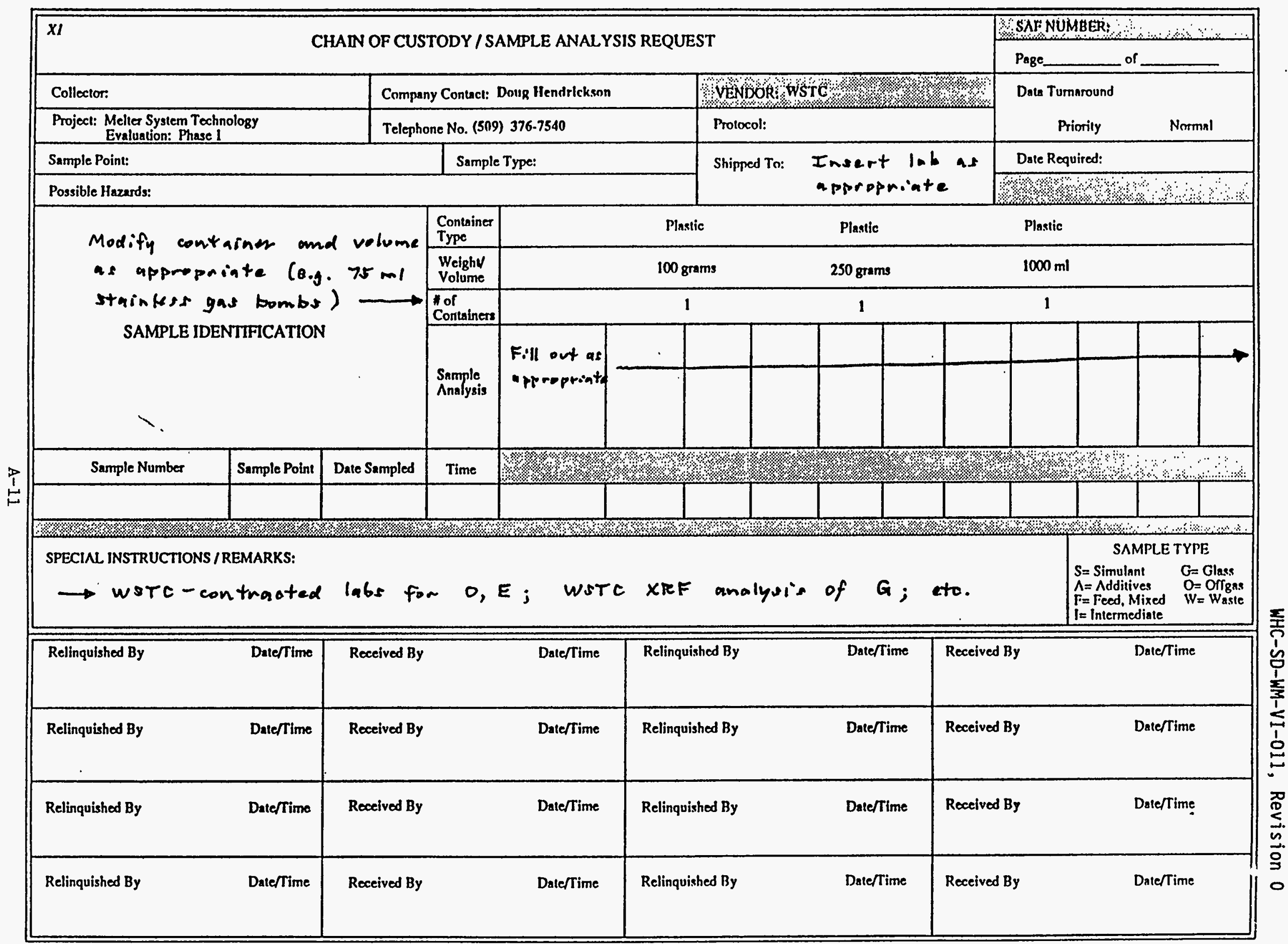


WHC-SD-WM-VI-011

Revision 0

THIS PAGE IS INTENTIONALLY BLANK

A-12 